Review Paper

\title{
Sustainable water management in the Angkor Temple Complex, Cambodia
}

\author{
Kosal Chim ${ }^{1,2} \mathbb{D} \cdot$ Jon Tunnicliffe ${ }^{1} \cdot$ Asaad Shamseldin $^{2} \cdot$ Sambath Sarun $^{3}$
}

Received: 16 August 2020 / Accepted: 21 December 2020 / Published online: 11 January 2021

(c) The Author(s) 2021 OPEN

\begin{abstract}
The headwater catchment of the Siem Reap River has supplied the Angkor Temple Complex and surrounding communities since the twelfth century. The Angkor Temple Complex area consists of historical moats and barays (reservoirs) which are currently used to store the water from the Siem Reap River to maintain temple foundation, irrigate cultivation areas and provide floodwater storage. The Angkor Wat Temple, which is located in the complex, was constructed on a sandy alluvial substrate and needs a stable supply of water to avert land subsidence and destabilization of the temple foundation. In light of changing climate, land use and land cover (LULC) trends, it is crucial to examine the wide-ranging implications of reduced water supply for the Angkor Temple Complex. Using the Soil and Water Assessment Tool, this study seeks to assess the conditions necessary to provide sustainable streamflow to the Angkor Temple Complex. We modelled 30 scenarios of co-varied LULC and precipitation regime under a changing climate. The results show that under most LULC scenarios, sufficient water resources can be harvested to supply the complex-however-any further loss of forest cover is likely to impact groundwater conditions, flood management and dry season shortages. Conversely, the water supply to the complex is shown to be sensitive under the range of climate scenarios explored; a reduction of more than $10-20 \%$ in mean annual precipitation was enough to put the water supply under stress for the current and future conditions of the complex.
\end{abstract}

Keywords Soil and water assessment tool (SWAT) - Siem reap river · Climate change $\cdot$ Land use change $\cdot$ Angkor Wat temple $\cdot$ Water supply

\section{Introduction}

Siem Reap River is a tributary of the Tonlé Sap (Great Lake) [1]. The Siem Reap River has played a crucial role in supplying the Angkor Temple Complex and the surrounding population for hundreds years. This complex consists of surface reservoirs, moats, canals, diversion weirs and numerous ancient temples. Normally, the water resource from this river has been diverted for storage in the complex (reservoirs and moats) during the rainy season. It has been used for households and irrigation purposes, sustaining the groundwater resource as well as maintaining the geotechnical stability of the Angkor Wat Temple structures. The base of the Angkor Wat Temple was constructed on a sandy alluvial substrate [2], which is particularly susceptible to subsidence in the event of any drawdown of the local water table. A stable supply of water of groundwater from the Siem Reap River is therefore required to avert any instabilities within this ancient structural foundation. This temple is an iconic site of spiritual and cultural significance and one of the biggest religious temples in the world [3]. There is a profound spiritual connection to the temple for

$\triangle$ Kosal Chim, chimkosal@yahoo.com | ${ }^{1}$ School of Environment, The University of Auckland, Auckland 1010, New Zealand. ${ }^{2}$ Faculty of Engineering, The University of Auckland, Auckland 1010, New Zealand. ${ }^{3}$ Ministry of Water Resources and Meteorology,

Phnom Penh 12300, Cambodia. 
both the local population and regional Buddhist community. It is estimated that around one million foreign tourists visit the temple annually [4], many of whom feel an important historic, cultural or spiritual connection. It also features as the centrepiece of Cambodia's flag, making it a symbol of national identity [5]. Thus, the Siem Reap River plays a valuable role in preserving the cultural, spiritual, religious heritage and national identity of Cambodia.

Alteration of the landscape by humans and shifting weather patterns due to climate change have impacted river systems and their diverse ecological populations, globally [6]. Land use and land cover (LULC) change is considered to be a major cause of altered surface runoff [7]. It can further impact temperature, wind speed, soil moisture and evapotranspiration at the local scale [8], all of which contribute to changes in river flow. Studies and reviews on the impact of land use change-particularly forest cover-upon hydrologic processes have been carried out at regional and global scales [9, 10]. Brown et al. [9] reviewed paired catchment studies on the impact of forest cover changes on water yield at different temporal scales; they reported that expansion of forest cover could reduce water yield. Likewise, Bruijnzeel [10] reviewed research on the hydrological function of tropical forests in south-east Asia and reported that water yield tends to increase with decreasing forest cover. Farley et al. [8] also found that runoff was reduced with afforestation, based on a compilation of data from 26 catchments around the globe. Thus, while there some established basis for the link between decreasing forest cover and higher water yields [9], it is important to look at the impact of forest cover on other aspects of hydrology, such as evapotranspiration, soil water content, dry season flows and flooding. Forest cover plays a crucial role in evapotranspiration and infiltration, as well as maintaining the available water storage capacity of the soil reduction of forest cover results in lower and higher streamflow during the dry and rainy seasons, respectively $[9,10]$. Furthermore, using observation data for a decade (1990-2000) of data from 56 countries around the world, Bradshaw et al. [11] investigated the mechanisms by which deforestation amplifies flood risk, and showed that forest cover can increase interception and evapotranspiration which in turn can lead to reduced flood-related catastrophes. While it is crucial to understand the streamflow, groundwater and evapotranspiration responses under forest cover, these might not reveal the whole story, since soil moisture interactions also play an important role in water balance under the influence of forest cover [9].

Land use in the Siem Reap watershed has been altered considerably in the last 30 years. Gaughan et al. [12] carried out a study on land use changes (1989-2005) within the whole Siem Reap catchment. They found an expansion of agriculture and charcoal production to be the major direct causes of landscape change, and they concluded that the expansion in the tourism sector is the driving force behind these changes. Furthermore, Le Billon [13] showed that forested areas have been heavily exploited for timber as a result of the peace-making process, since this area was part of the Khmer Rouge reintegration policy. Similarly, Chim et al. [14] conducted a study on land cover change for an upper Siem Reap watershed using satellite images (1988-2018) and land change model in the TerrSet software (Clark Labs). They discovered a remarkable pace of deforestation-roughly $37 \%$ of forest cover has disappeared over the last 30 years-with the annual rate averaging $1.22 \%$. These rates are roughly similar to the Mekong countries (Cambodia and Myanmar), which have had a mean rate of $1.20 \%$ forest land cover loss annually, between 1990 and 2015 [15]. Chim et al. [14] also projected that current trends are likely to continue into the future, given current land management and governance practices within the watershed.

In addition to LULC change, climate clearly exerts a firstorder influence upon hydrologic regime and streamflow generation processes in the watershed [16]. Rising temperature affects the water cycle, including evapotranspiration, runoff and water yield [17]. In a monsoon-dominated climate such as Cambodia's, changes to the timing of rainfall inputs may strongly affect the annual water storage balance, and thus streamflow trends with the catchment. At the national scale, Thoeun [18] looked for trends in Cambodian climate records, and he found that the annual mean temperature has increased by $0.8^{\circ} \mathrm{C}$ since 1950 , a rate of $0.023^{\circ} \mathrm{C}$ annually. The annual dry season precipitation totals appear to have declined at a rate of $0.184 \%$ per year. Recent work by Chim et al. (in press) used downscaling of climate change models to show that there is likely to be a continuing, increasing trend in temperatures ( $\max$, avg, $\min$ ), and a decreasing trend in precipitation in the twenty-first century for the upper Siem Reap watershed. Moreover, Oeurng et al. [1] undertook an assessment of future climate trends for the tributaries of the Tonlé Sap Basin more broadly, applying three different General Circulation Models (GCMs). They discovered that the future annual average flows (2021-2100) in the Siem Reap River were likely to decrease significantly, from 40 to $70 \%$ relative to baseline (1999-2015).

Regionally, modelling work has indicated that climate change is likely to exert a relatively stronger effect on streamflow yield than LULC. For instance, Khoi and Suetsugi [16] modelled streamflow under the effects of diverse land use and climate changes in the Be River Catchment located in Vietnam. They found that a $0.2-0.4 \%$ reduction in water yield was attributable to LULC change, and a decrease in streamflow of $0.7-6.9 \%$ could result from climate change. Similarly, Yan et al. 
[19] concluded that climate change has a greater impact on streamflow relative to LULC change in the Xinjiang Basin located in the west of China. Another study on the impact of LULC change in China, on the Zamu River basin, by Wang et al. [20] found that there would be a small reduction of mean annual runoff, around $2.3 \%$, as an outcome of future afforestation (up to $25 \%$ of the watershed area).

While some research has been done on the impacts of land cover and climate changes on hydrology in tropical countries including Laos PDR [21], Vietnam [16] and Malaysia [22], relatively little research has been done to identify the critical thresholds for forest cover [23] and precipitation variation required for sustainable streamflow of the Siem Reap catchment. In order to provide effective advice for managing water yield in this river, it is important to identify these thresholds for both individual and joint effects of land cover and climate changes: the points along this trajectory of change at which the river can no longer reliably and sustainably supply water to the Angkor Temple Complex. Under the effect of LULC, this study carried out further investigation into the impact of forest cover on the dry season streamflow and groundwater contribution to stream and the amount of water stored in soil before making generalization of reduction forest could increase water yield. This study assessed both the individual and collective impacts of these factors on Siem Reap streamflow. This research presents a new case study for Cambodia and fills an important research gap in identifying threshold(s) for sustainable streamflow in the basin under both individual and combined impacts.

The Soil and Water Assessment Tool (SWAT) model was adopted to examine these individual and collective impacts of landscape and climate changes on river flow. SWAT has been employed to assess solely the impact of land use [24] and solely the effect of climate change on hydrology [1,25]. The model also has been widely applied to model the combined effects of both land cover and climate changes on hydrology in river basins across the globe, including the EU [26], USA [27] and Vietnam [16].

The first objective of this paper was to identify the proportion (\% area) of forested lands in the watershed necessary to sustain water yield to the Angkor Temple Complex, through the action of flow interception, improved water stored in soil and groundwater. The second objective was to determine the critical threshold for climate variation, in particular, the necessary cumulative annual precipitation required to provide sustainable water storage within the complex. The last objective was to explore the combined effects of these impacts (forest cover and annual precipitation) to assess any interactions that might moderate (or intensify) any individual impacts on the river water supply to the Angkor Temple Complex.

\section{Study area}

The study site is located in the Siem Reap Province, in the north-west of the country. This province is a major tourism area because it is home to the Angkor Wat Temple. The temple is located within the Angkor Temple Complex, a World Heritage Site. The Angkor Temple Complex (pink boundary, Fig. 1) includes a number of water storage reservoirs known as barays. The Angkor Temple Complex is located approximately $5 \mathrm{~km}$ from the Siem Reap city centre, and it is around $324 \mathrm{~km}$ from the capital city (Phnom Penh). The terrain of the Angkor Temple Complex area has relatively subdued, gently sloping topography, with elevations ranging from approximately 20-30 m above mean sea level (a.m.s.l.). The upper catchment, used to be the Puok River and including Mount Kulen or Phnom Kulen, has elevations up to approximately 450 a.m.s.l (the top of the mountain). The soil types in the Angkor Temple Complex region are red-yellow podzols and acid lithosols, with planosols, cultural hydromorphics, grey hydromorphics, alluvial lithosoils and lacustrine alluvial soils [28]. The soils in mountainous area are derived from the underlying sandstone and conglomerate strata, as well as alluvium and colluvium, composed mainly of sand, silt, clay and laterite.

The Siem Reap River is a tributary of the Tonlé Sap with a river length of approximately $90 \mathrm{~km}$. It flows from headwaters surrounding Phnom Kulen and drains to the Great Lake through the Angkor Temple Complex and Siem Reap City. It is also a main water source for the Angkor Temple Complex and municipality. This study has limited analysis to the upper part of the Siem Reap River watershed because discharge downstream from this point passes through a number of diversion gates and weirs (depending on river flood stage and reservoir capacity; see below), with only limited monitoring of the diverted flows. The neighbouring Pouk and Rolous rivers contribute to the West and East barays (respectively), though they have no hydrological data, either. As a result of this, it is difficult to reconstruct the annual water mass balance for this downstream portion of the basin. However, the headwater catchment is the majority source area for the temple complex.

\subsection{Hydrometeorology}

Data from two rainfall stations are available in the study area. The Siem Reap station is located on the grounds of the Provincial Department of Water Resources, around $20 \mathrm{~km}$ from the upper Siem Reap catchment. The Banteay Srie station is located in the study catchment and it 


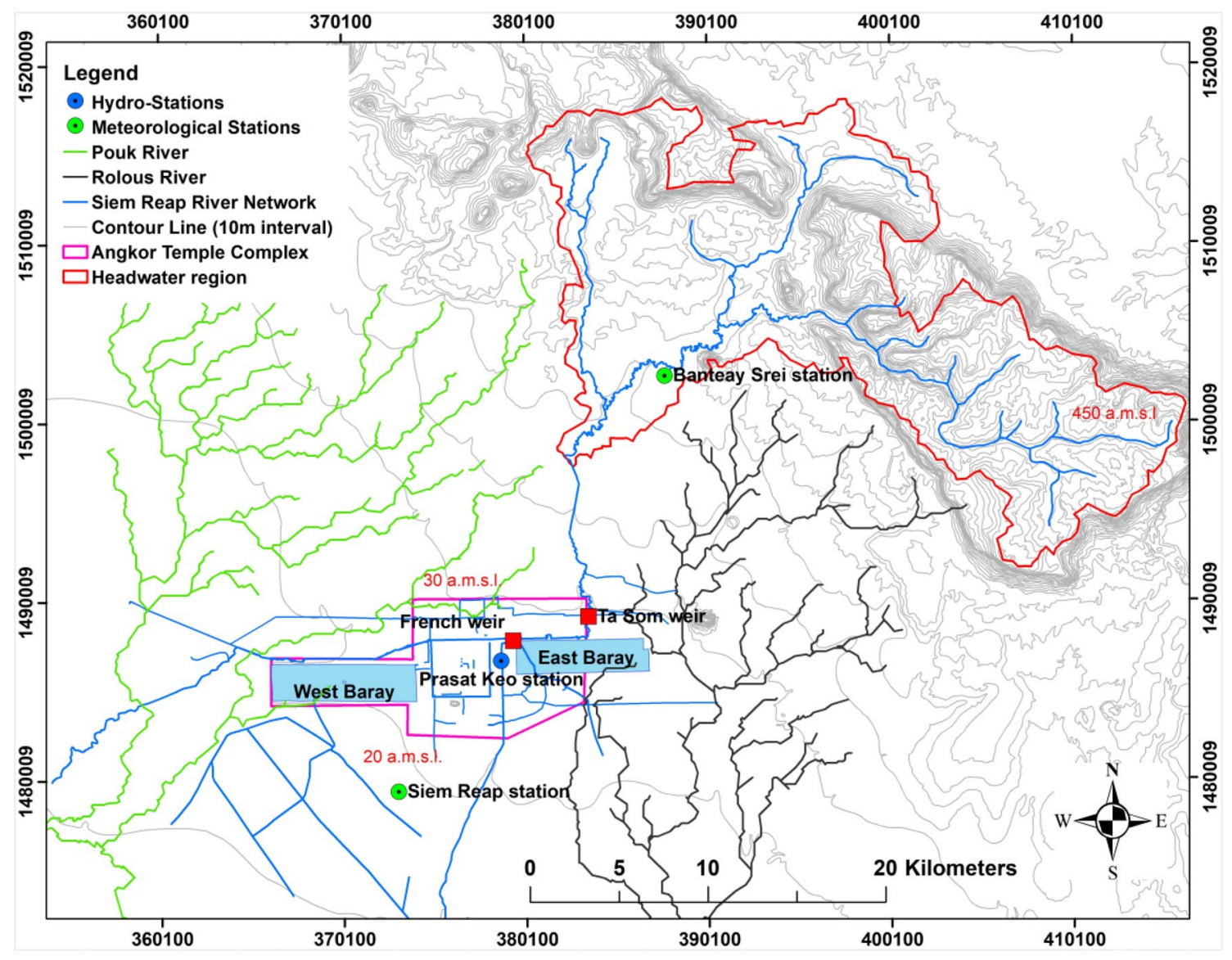

Fig. 1 Location of the study area. Drainage network and canal system for the Angkor Temple Complex. The primary water source for the complex derives from the headwaters of the Siem Reap River. Hydrological and climate stations are indicated

is around $10 \mathrm{~km}$ from the range of Phnom Kulen. According to the Siem Reap provincial department [29], the annual mean temperature, max and min temperature values are $28^{\circ} \mathrm{C}, 34^{\circ} \mathrm{C}$ and $24^{\circ} \mathrm{C}$, respectively (based on dataset from 1998 to 2018). At the Siem Reap station, the annual average precipitation is $1475 \mathrm{~mm}$ (based on dataset from 1988 to 2018). At the Banteay Srie station, the annual average rainfall is $1160 \mathrm{~mm}$, though this station was not installed until 2000 (based on dataset from 2000 to 2018). Our study used the available information from the Siem Reap (SR) and Banteay Srie (BTS) stations, as summarized in Fig. 2.

Prasat Keo hydrological station is the only available gauge station on Siem Reap River. It is positioned in the Angkor Temple Complex area, below the diversion weirs. Based on the gauging records at Prasat Keo station, Cambodia, the annual average streamflow is $6.27 \mathrm{~m}^{3} / \mathrm{s}$. The minimum and maximum monthly average flow values are $0.82 \mathrm{~m}^{3} / \mathrm{s}$ and $20.26 \mathrm{~m}^{3} / \mathrm{s}$, respectively (based on data from 1999 to 2018). No hydrological gauge station is available above the weirs (i.e. the principal study area), introducing another limitation in the available dataset. It has been determined by the water manager [30], however, that the record is reasonably representative of flows in the dry season (November to April) since the flow during rainy season is influenced by the diversion weirs. Some estimation is required to account for diversion of peak flows during the rainy season.

\subsection{Water management in the Angkor Temple Complex}

Water supply in the Angkor Temple Complex has been managed by the Apsara Authority, Cambodia. Sources of water are mainly from natural rivers (surface water) and groundwater. The water management in this river is different from ordinary rivers because some proportion of annual flows must use to support the Angkor Temple Complex, which is a part of world heritage. According to figures provided in a meeting with the Apsara Authority officials in early 2019, the Angkor Temple Complex can currently store about 65 million $\mathrm{m}^{3} /$ year [30].

There are four main surface reservoirs and moats in the Angkor Temple Complex. Firstly, the North Baray can take 
Fig. 2 Average temperature and precipitation data in the study area. Background shading shows the annual monsoon cycle, which strongly governs the annual precipitation trends

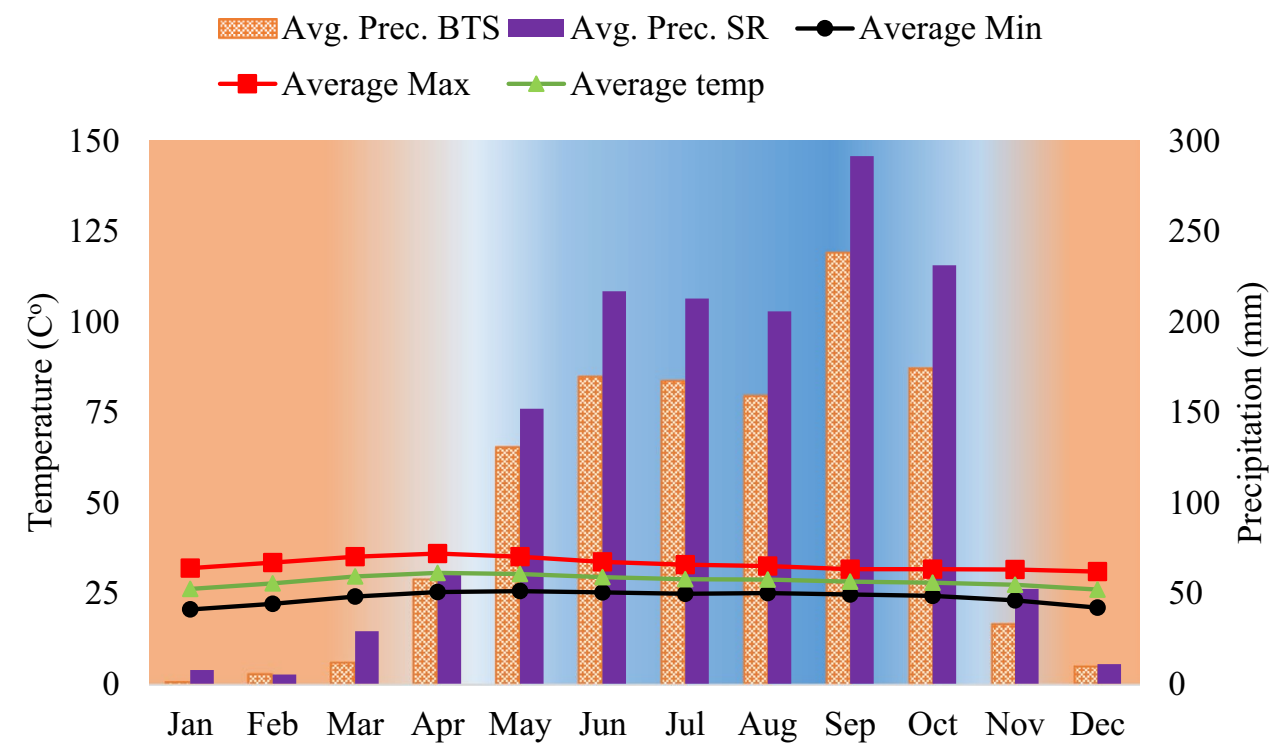

up to about 5 million $\mathrm{m}^{3}$, and it has been used to supply the water for Prasat Neak Pon, Prasat Preak Khan Moat and the Angkor Thom Moat. There is strong groundwater-surface water coupling between the North Baray and Prasat Preak Khan (located left side of the North Baray) and Neak Pon (located in the central part of the North Baray). When water from the Siem Reap River is diverted into the North Baray, the Prasat Preak Khan and Neak Pon will also be supplied. Secondly, the moat around Angkor Thom can hold about 2 million $\mathrm{m}^{3}$, sourced from the Siem Reap River. The moat around Angkor Thom temple will have water the whole year round after rehabilitation of the historic canal system by the Apsara Authority. Thirdly, the moat around Angkor Wat Temple can hold approximately 2 million cubic meters of water, sourced from the Siem Reap River. The moat around the Angkor Wat Temple plays a particularly important role in supporting the Angkor Wat Temple; it surrounds the foundation, effectively mitigating against subsidence. Fourthly, the West Baray can store approximately 56 million $\mathrm{m}^{3}$; the water sources are mainly from the Siem Reap River and partially from Pouk watershed. It is the largest reservoir in the Angkor Temple Complex. These storage sites have played a vital role in preventing and mitigating natural disasters, including flooding and drought events in Siem Reap City [30]. While the North Baray, the Preak Khan Maot, the Angkor Thom Moat and Angkor Temple Moat have been used to regulate of groundwater recharge and strengthen foundation of the temple, the West Baray has been used to irrigate agricultural areas and control flooding [31].

The Apsara Authority is also planning to rehabilitate the East Baray and Baray Loley in the forthcoming year. After rehabilitation, the East Baray will have the capacity to store 36 million $\mathrm{m}^{3}$, sourced from the Siem Reap River and the
Rolous River. Baray Loley has the capacity to store 10 million $\mathrm{m}^{3}$ and has the same water sources as the East Baray. Upon completion of rehabilitation (in the near future), the total capacity of the Angkor Temple Complex will be approximately 111 million $\mathrm{m}^{3}$. According to the Apsara Authority officials, the purpose of this rehabilitation is to ensure the necessary supply to accommodate an increasing population and tourists in the Siem Reap City, improve groundwater recharge and to prevent flooding.

Based on the report of JICA [32], the annual pan evaporation in Siem Reap River was $1542 \mathrm{~mm}$. Although this is a coarse estimate of annual evaporation loss, if this component was included in the water demand estimation in the Angkor Temple Complex, the current storage would be about 97 million $\mathrm{m}^{3}$ (current storage 65 million $\mathrm{m}^{3}$ plus evaporation loss 32 million $\mathrm{m}^{3}$ — with the storage surface area around $21 \mathrm{~km}^{2}$ ). Since about half of the East Baray and Baray Loley have roads, household and other physical infrastructure within their bounds, the size of the future rehabilitated barays might be reduced. This study considers only the surface area of the water reservoirs, including barays and moats in the Angkor Temple Complex, roughly $31 \mathrm{~km}^{2}$ in total, after rehabilitation. The total evaporation loss for this scheme is thought to be approximately 48 million $\mathrm{m}^{3}$.

The current water conveyance system consists of canals, diversion weirs, pipe culverts, spillways, pipe culverts with sluice gate, box culverts, box culverts with sluice gate, bridges and wooden bridges which have been used to distribute water throughout the Angkor Temple Complex. There are two diversion weirs in this complex: French Weir and Ta Som Weir in the complex (Fig. 3). The French Weir was constructed in 1937, and it is located in the northeast part of the Angkor Temple Complex. Ta Som Weir was 


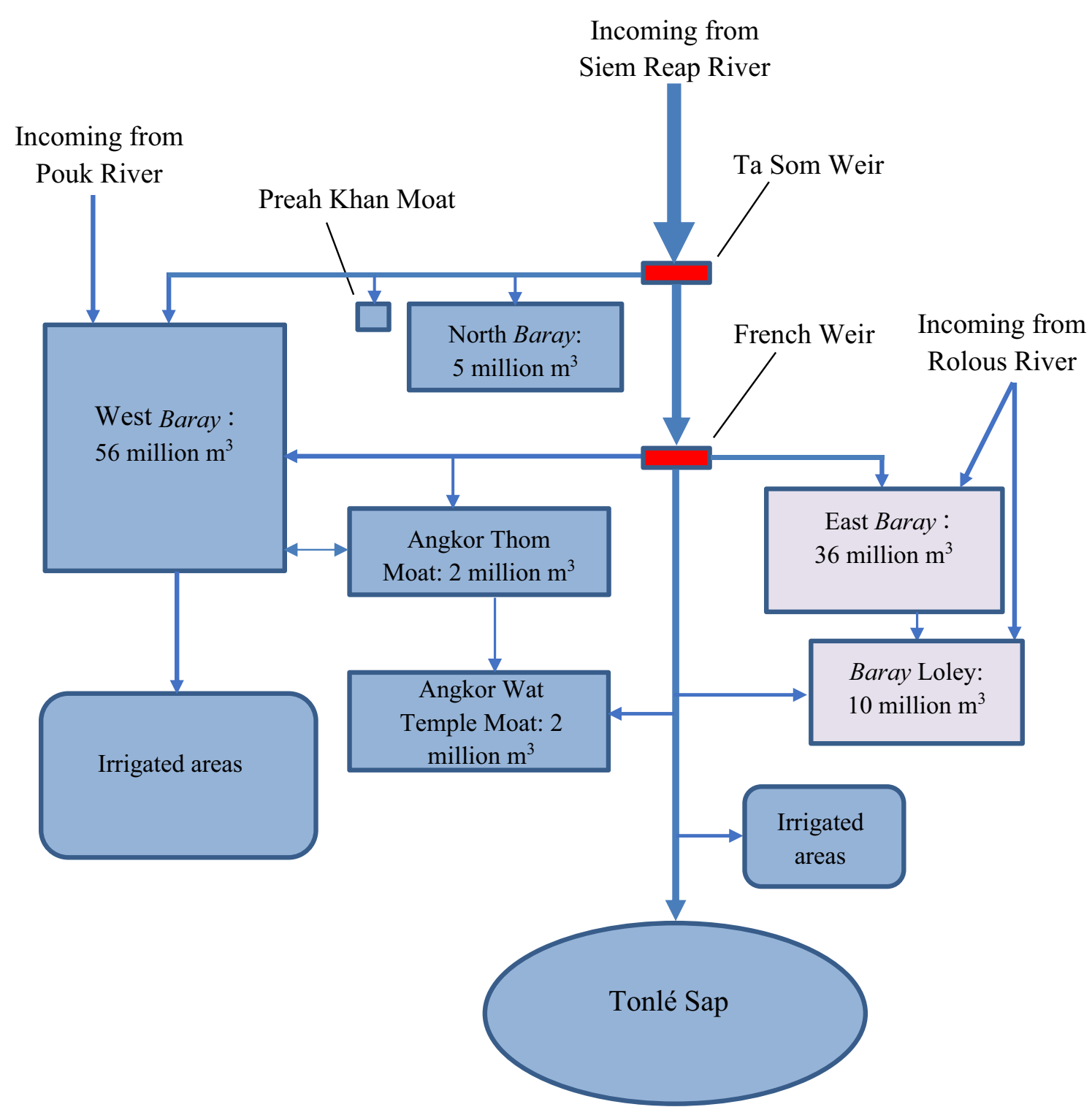

Fig. 3 Canal system and structures within the Angkor Temple Complex (blue colour represents the current storage and lighter purple shows the future rehabilitation storage)

constructed in 2006 and it is located within the upper storage zone of the French Weir. They are both used to divert water into the complex.

Another important reservoir of water in the Angkor Temple Complex is the local aquifer. In addition to surface water from the Siem Reap River, groundwater has played a significant role in maintaining a stability foundation of the Angkor Wat Temple. The groundwater is easily accessible as the water table lies between depths of less than $1 \mathrm{~m}$ and $5 \mathrm{~m}$ in the rainy and dry seasons, respectively [28]. Assessment of groundwater had been carried out by JICA using the electric sounding, very low frequency (VLF) electromagnetic prospecting, monitoring around 100 existing wells and new drilling wells. Further detail of this groundwater study can be found in their report [32]. Numerous households and hotels use groundwater for their daily consumption through wells. As the number of visitors [12] and hotels [33] increase in Siem Reap City, significant volumes of water will be pumped from groundwater sources. Over-extraction of groundwater may lead to a drop in the groundwater table, which could in turn eventually lead to compromised stability of the Angkor Wat Temple. JICA [32] has estimated the average water demand in Siem Reap City in 2010 was around $12,000 \mathrm{~m}^{3}$ per day ( 4.38 million $\mathrm{m}^{3}$ per year). Based on their simulations of groundwater extraction, $12,000 \mathrm{~m}^{3}$ per day was found to be a likely safe upper limit for extraction, as it is not likely to lead to land subsidence issues. However, 
a study carried out by ADB [34] in 2014 estimated that the Siem Reap City water supply would have to provide a total of $25,000 \mathrm{~m}^{3}$ per day (9.13 million $\mathrm{m}^{3}$ per year) in order to supply a flourishing tourism sector and associated industries. The study also estimated that in order to divert many hotels from groundwater usage, $60,000 \mathrm{~m}^{3}$ per day ( 21.90 million $\mathrm{m}^{3}$ per year) would be required. If the city water supply were to shift from groundwater to surface water sources (using water from the West Baray, 56 million $\mathrm{m}^{3}$ ), it would likely halt the decline of the groundwater table, therefore improving geotechnical stability in the areas immediately surrounding the Angkor Wat Temple.

\section{Material and methods}

\subsection{Model time series}

Daily hydrometeorology data were obtained from the Department of Hydrology under the Ministry of Water Resources and Meteorology (MOWRAM), Cambodia. Weather data (precipitation and temperature) from 1996 to 2018 were used in conjunction with the SWAT model, with the initial three years (1996-1998) used to warm up the model. Hydrological data from 1999 to 2018 were used for calibration (1999-2010) and validation (2011-2018).

The shape files of the Angkor Temple Complex, barays, moats, canals system, location of weirs, climate and hydrological stations were obtained from the Apsara Authority, MOWRAM, and Siem Reap Provincial Department of Water Resources and Meteorology (PDWRAM). A soils map of the study catchment was obtained from the FAO and this can be downloaded at http://www.fao.org/geonetwork/srv/ en/metadata.show?id=14116 (at the scale of 1:3,000,000). A digital elevation model (DEM) of the study catchment was collected from the United States Geological Survey (USGS), with $30 \mathrm{~m}$ resolution. It is available from http:// earthexplorer.usgs.gov/.

The annual average precipitation of both stations (the Siem Reap City and Banteay Srey) was $1337 \mathrm{~mm}$ (1999-2018). Change scenarios for both individual and combined variables, modulated about $\pm 50 \%$ from this current condition, are modelled forward to explore the potential hydrological responses. In the case of climate change scenarios, the $\pm 50 \%$ precipitation range was selected for the following reasons: (1) the $+50 \%$ precipitation (about $2005 \mathrm{~mm}$ ) is not too far from the maximum annual average for precipitation observed in the watershed $(1926 \mathrm{~mm})$ which occurred in the watershed in 2013 and (2) the -50\% precipitation (around $668 \mathrm{~mm}$ from the current precipitation regime) is not far from recent forecasts by Chim et al. (in press), showing that the mean annual precipitation was projected to decrease by $56 \%$ and $54 \%$ (about 588 and
$615 \mathrm{~mm}$ ) over twenty-first century under scenarios the Representative Concentration Pathway (RCP) 2.6 and RCP 4.5 , respectively. RCP is a new set of climate change scenarios for the Intergovernmental Panel on Climate Change (IPCC) Fifth Assessment [35]. Moreover, the future annual average flow of Siem Reap River was likely to decrease significantly [1]. This evidence might imply that the precipitation would decrease around 50\%; hence, it could drop the streamflow (40-70\%). We therefore stratified a range of precipitation rates into ten scenarios, from $-50 \%$ to $+50 \%$ relative to the current annual average, in 10\% increments. While the anticipated real-world scenario is likely to involve an overall decrease in precipitation, this spread of modelled values provides the opportunity to look for any nonlinear behaviours, or other anomalies within the suite of results.

In this study, we not only consider changes in precipitation, but we also look at concomitant changes in temperature. We assume that the mean annual temperature will increase from 1 to $10 \%$, not far off recent model forecasts by Chim et al. (in press). They found that the annual average temperature in the study watershed pointed towards an increase of $6 \%$ for RCP $2.6,8 \%$ for RCP 4.5 and $11 \%$ for RCP 8.5 scenarios, over the twenty-first century. This increase of $10 \%\left(30.8^{\circ} \mathrm{C}\right)$ in annual average temperature is approximately $2.80^{\circ} \mathrm{C}$ higher than the annual average $\left(28^{\circ} \mathrm{C}\right)$ currently observed.

Climate change scenarios involved an appropriate co-variation of precipitation and temperature rates. The scenario 'Clim - 50\%' was obtained by combining a $50 \%$ decrease in precipitation and $a+1 \%$ increase in temperature, relative to current climate conditions. Similarly, the scenario ' $\mathrm{Clim}+50 \%$ ' involves both a $50 \%$ increase in precipitation and a $10 \%$ increase in temperature, relative to the current climate regime. Therefore, there were ten climate change scenarios that were modelled forward to explore the possible streamflow responses.

Chim et al. [14] conducted a study of land cover change in upper Siem Reap that future forest cover is likely to decrease from $44 \%$ (current land use) to $23 \%$ and $22 \%$, in years 2048 and 2098, respectively, given current land management and governance practices within the watershed. LULC maps for 2018 were developed by Chim et al. [14] and these were employed to generate LULC maps scenarios in this study. Applying the Expand and Shrink functions under the Spatial Analyst toolbox in ArcGIS, either increasing or decreasing proportions of forest pixel cover could be generated. Similar to climate change scenarios, there were ten LULC map scenarios. The relative insensitivity of streamflow discharge to changes in LULC change has been documented [9]; adjustments of $20 \%$ forest clearance may have no effect on streamflow, and it may take up to $50 \%$ forest cover change in order to detect the 
streamflow change. Accordingly, this study endeavoured to explore streamflow responses under a wide range of forest cover (+51 and $-39 \%)$, relative to current conditions. For the 'increased forest cover' scenarios from LULC 2018 ( $44 \%$ of forest and $56 \%$ of agriculture cover), we generated maps with $+13,+21,+31,+43$ and $+51 \%$ (equal to $57,65,75,87$ and $95 \%$ forest cover of the watershed) while the 'decreased forest cover' scenarios were run in the opposite direction: $-12,-20 \%,-29 \%$ and $-39 \%$ (equal to $5,15,24$ and $32 \%$ forest cover of the watershed). The decreased forest cover in the future might represent the outcome of future forest management in the catchment, owing to poor enforcement of laws and regulations. During a field visit in early 2019, it was observed that new roads are under construction which could promote further deforestation, and medium-scale agriculture continues to expand on Phnom Kulen. Although a substantial increase in forest cover does not reflect recent trends in the catchment, given the current political situation and approach to land management, the future government might consider forest cover expansion plans in the catchment, such as forest plantation and forest regeneration, in order to improve the ecosystem and cope with future climate change in the watershed area. Thus, we have broadened the domain of possible boundary conditions in order to explore a full range of variability. This exploration of parameter space is also helpful in framing the overall influence of land cover on hydrologic response. Afforestation of the catchment would likely improve water storage, capture carbon and cool surface temperature [36]. It could furthermore mitigate against other effects of future climate change, such as increasing groundwater recharge, and improving the groundwater resource [37], and attenuating the flood peaks in future flood events [38].

As a further point, in generating the various distributions of land cover, this study ignored the human factors that guide forest removal (i.e. suitably low-relief terrain, soil distribution and other factors) since we are focused on the rate change of LULC (forest and non-forest areas) rather than the exact pixels of change in the watershed. All the LULC scenarios in our model suite are shown in Fig. 4.

LULC scenarios consisted of increasing forest cover up to $+51 \%$ and decreasing forest cover to $-39 \%$, relative to the current situation (land use 2018 map) and climate came from increasing $+50 \%$ and decreasing $-50 \%$ of precipitation from the baseline (1999-2018). Beside the above-mentioned climate and LULC scenarios, there were combined scenarios of both impacts. While the Com - 01 comes from the combination of the increasing $51 \%$ forest cover ( $95 \%$ forest areas of the watershed),$+50 \%$ precipitation and $+10 \%$ temperature relative to the current land use and climate regime, the Com - 10 comes from the combination of decreasing $-39 \%$ forest cover $(5 \%$ forest cover of the watershed), $-50 \%$ precipitation and increasing $+1 \%$ temperature from the current land use and climate regime. With these combined scenarios, we wanted to explore a wide range of variability in controlling variables and streamflow responses, although some scenarios might not represent plausible conditions in the watershed. In total, there were thirty scenarios (Fig. 5), which consisted of ten scenarios for LULC change (Green points), ten scenarios for climate change (Blue points) and ten scenarios for a combination of both LULC and climate change (Red circles).

\subsection{Sustainable threshold for the Angkor Temple Complex}

The sustainable threshold for the Angkor Temple Complex was assessed based on the required storage capacity within the Angkor Temple Complex, evaporation loss from those storage reservoirs and environmental flow requirements for the Siem Reap River. Conditions required to sustain current demand were predicated on currently available storage volumes; future sustainable thresholds were based on reservoir capacity that is currently being developed. The water demand for the current and future storage capacities of the Angkor Temple Complex are approximately 65 and 111 million $\mathrm{m}^{3}$, respectively [30]. The evaporation loss of the current and future storage capacities of the Angkor Temple Complex were calculated based on JICA [32] report on the annual pan evaporation in the Siem Reap River and the exposed surface area of the storage reservoirs. The environmental flow requirements for the Siem Reap River were generated according to the Tenant and Global Environmental Flow Calculator (GEFC) methods (further detail on these in the following section). The sustainable thresholds for the Angkor Temple Complex were adopted according to the following equations:

$\mathrm{ST}_{\text {Current }}=\mathrm{WD}_{\text {Current }}+E_{\text {Current }}+$ Avg. $\mathrm{EF}$ (Tenant \& GEFC)

$\mathrm{ST}_{\text {Future }}=\mathrm{WD}_{\text {Future }}+E_{\text {Future }}+$ Avg. $\mathrm{EF}($ Tenant \& GEFC)

where $\mathrm{ST}_{\text {Current: }}$ : current sustainable threshold, $\mathrm{ST}_{\text {Future: }}$ future sustainable threshold/sustainable threshold after rehabilitation, $W_{\text {Current }}$ : water demand for the current storage in the complex, $W D_{\text {Future }}$ : water demand for the future storage or after rehabilitation, $E_{\text {Current: }}$ evaporation loss for current storage, $E_{\text {Future }}$ evaporation loss for future storage or after rehabilitation, Avg. EF: average environmental flow based on the Tenant and GEFC methods.

An environmental flow is defined as the river flow required to maintain the function of downstream ecosystems [39]. There are many methods for determining environmental flows [40]; over 200 methods have been 
a

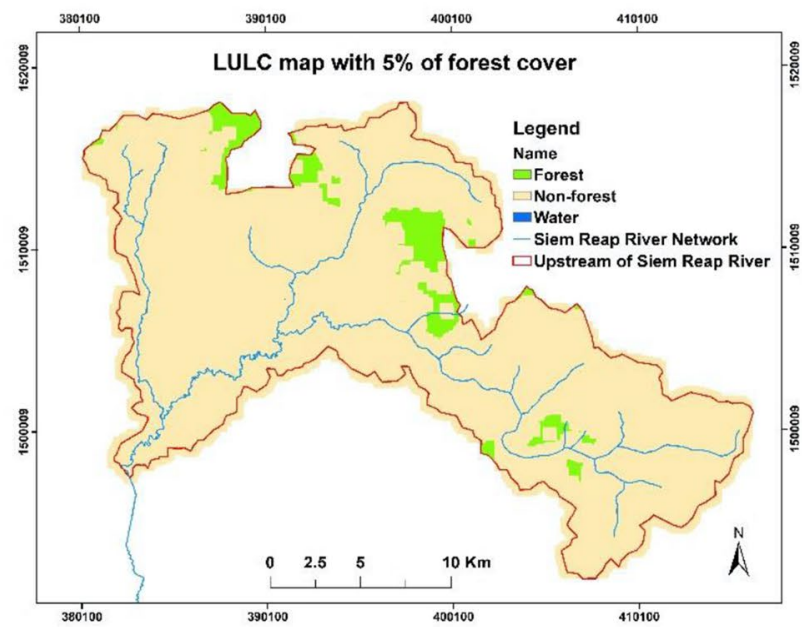

c

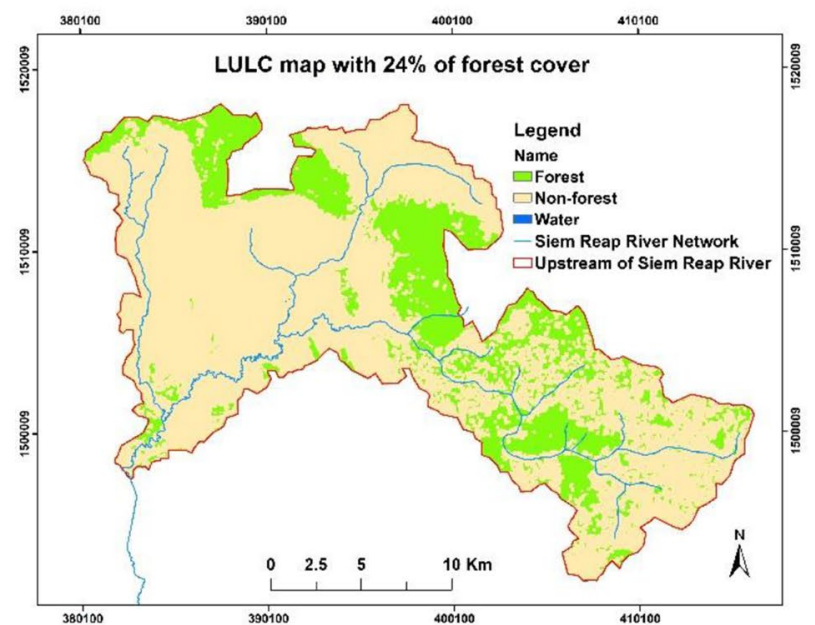

e

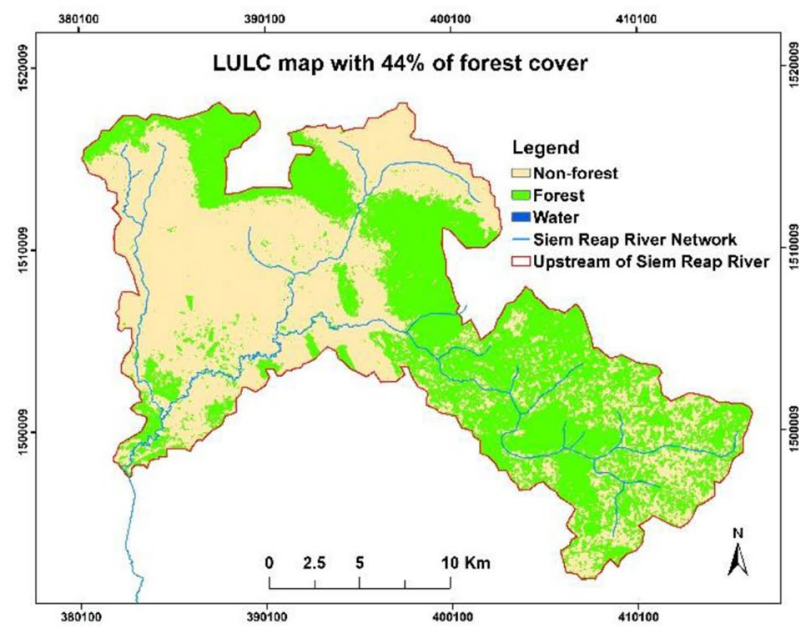

Fig. 4 LULC map scenarios: a with $5 \%$ forest cover, b with $15 \%$ forest cover, c with $24 \%$ forest cover, $\mathbf{d}$ with $32 \%$ forest cover, e LULC 2018-44\%forest cover, $\mathbf{f}$ with $57 \%$ forest cover, $\mathbf{g}$ with $65 \%$ forest $\mathrm{b}$

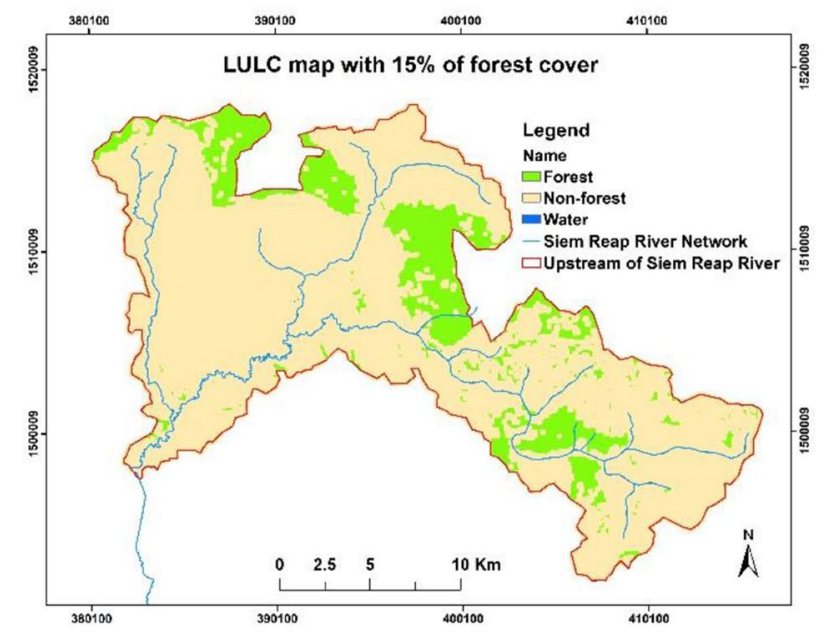

d
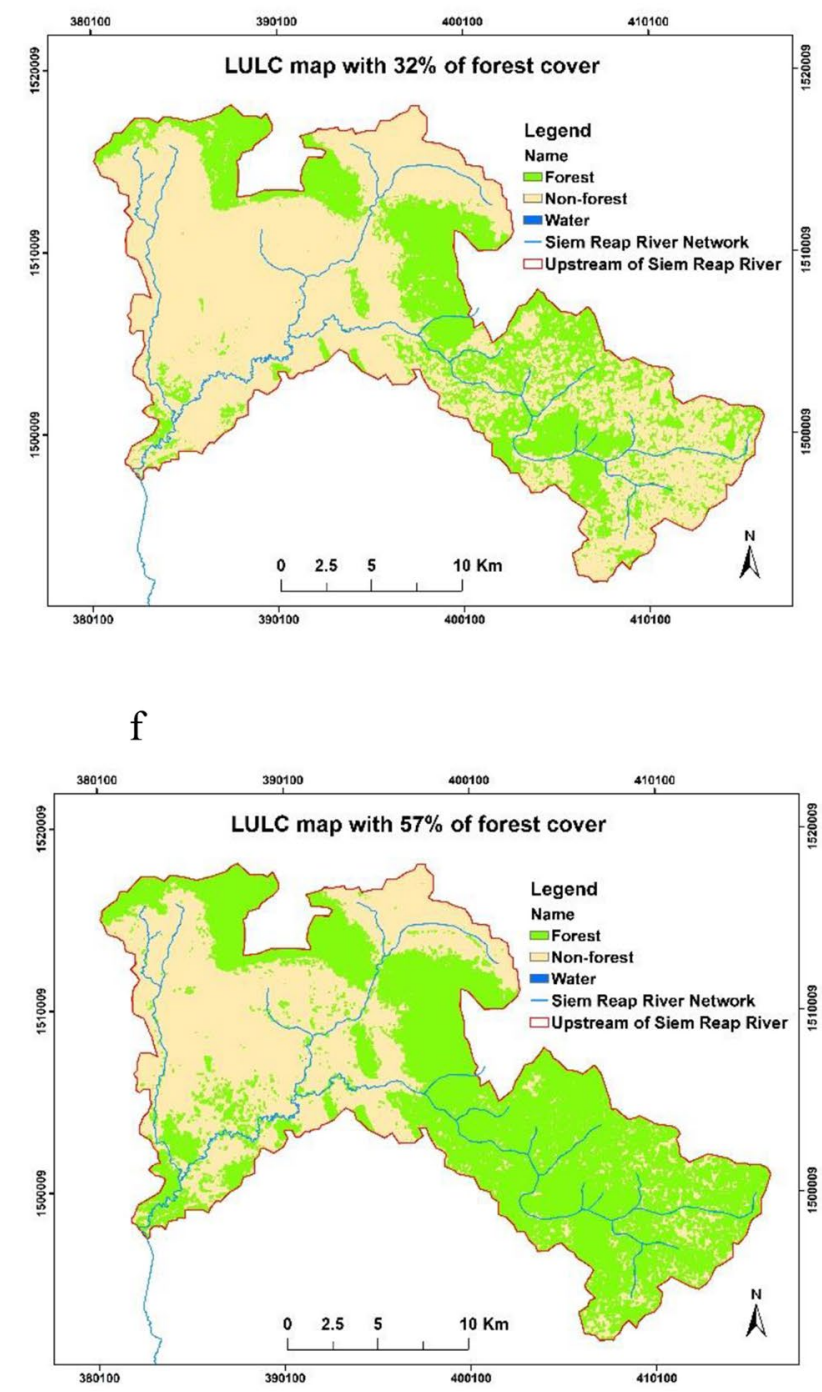

cover, $\mathbf{h}$ with $75 \%$ forest cover, $\mathbf{i}$ with $87 \%$ forest cover and $\mathbf{j}$ with $95 \%$ forest cover. Note that LULC 2018 consists of $44 \%$ of forest cover and $56 \%$ of non-forest/agriculture cover 


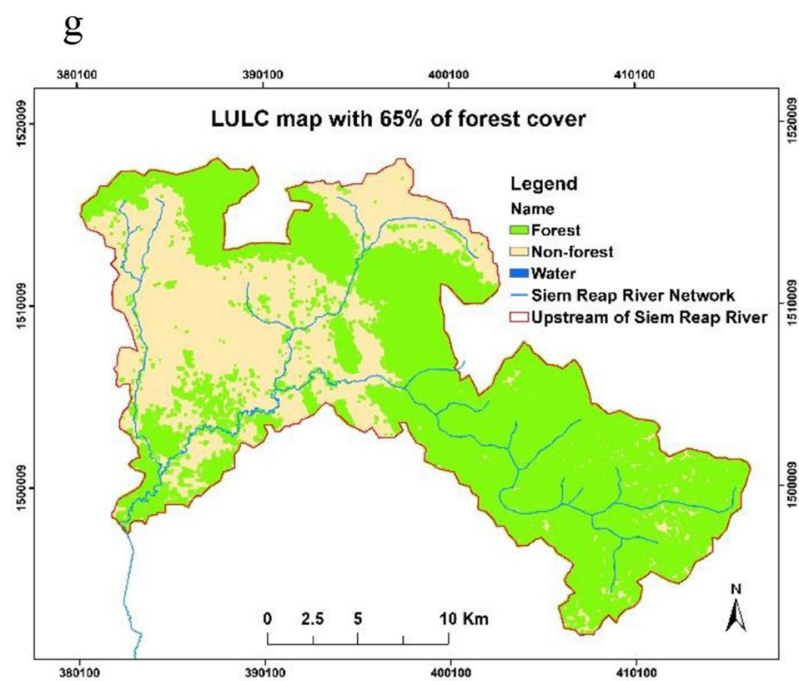

$\mathrm{h}$
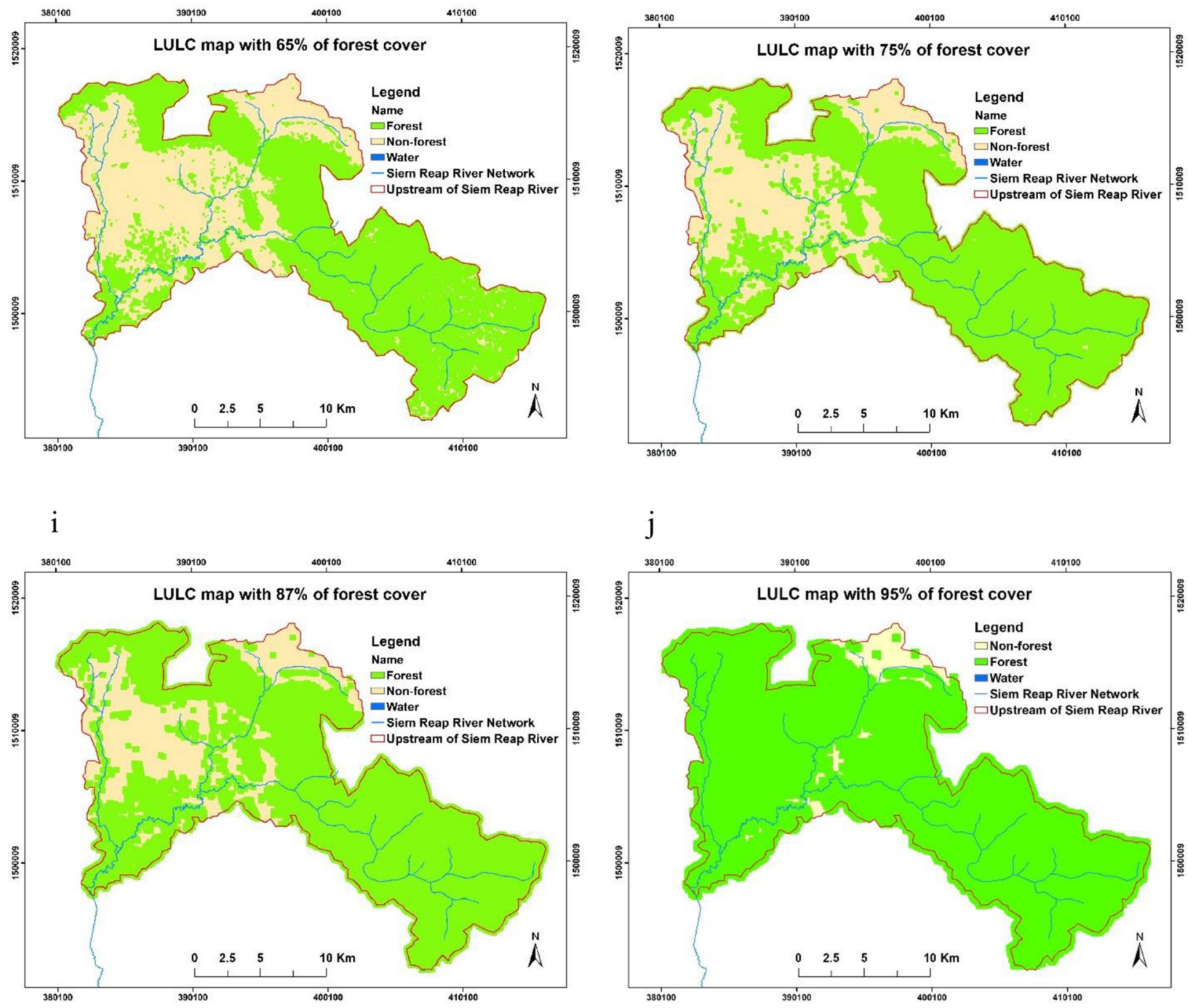

Fig. 4 (continued)

employed in 44 countries [39]. They are classified into four groups: hydrological, hydraulic rating, habitat simulation and holistic $[39,41]$. The Tennant method is the most commonly used method among hydrological methods [40, 42], and worldwide it has been used in more than 25 countries [39]. It is conceptualized using the empirical relationships between the mean annual flow (percentage) and ecological conditions [41]. The recommended environmental flows to maintain good habitat conditions, according to the Tenant method, were $20 \%$ of the rainy season mean flow and $40 \%$ of the dry season flow [41]. This percentage was adopted as a reasonable threshold to maintain the basic conditions for river habitat. However, this method is not based on a detailed habitat census, nor does it take into account of the socio-economic factors which influence regulation of the watershed.
The GEFC software is another hydrological method used for determining the environmental flow based on assessment of changes to the flow-duration curve (FDC) [41]. This software is freely available and was developed by the International Water Management Institute (IWMI) in collaboration with the Water Systems Analysis Group of the University of New Hampshire [43]. The application has been used to generate environmental flow regimes for various types of ecosystem conditions in the catchment using monthly streamflow data [41]. Environmental flows are established in order to maintain an ecosystem to some condition, or so-called environmental management class (EMC) in GEFC software [43]. There are six $E M C s$ in this software which range from 'A: Natural' to 'F: Critically Modified' as shown in Table 1. The GEFC was 


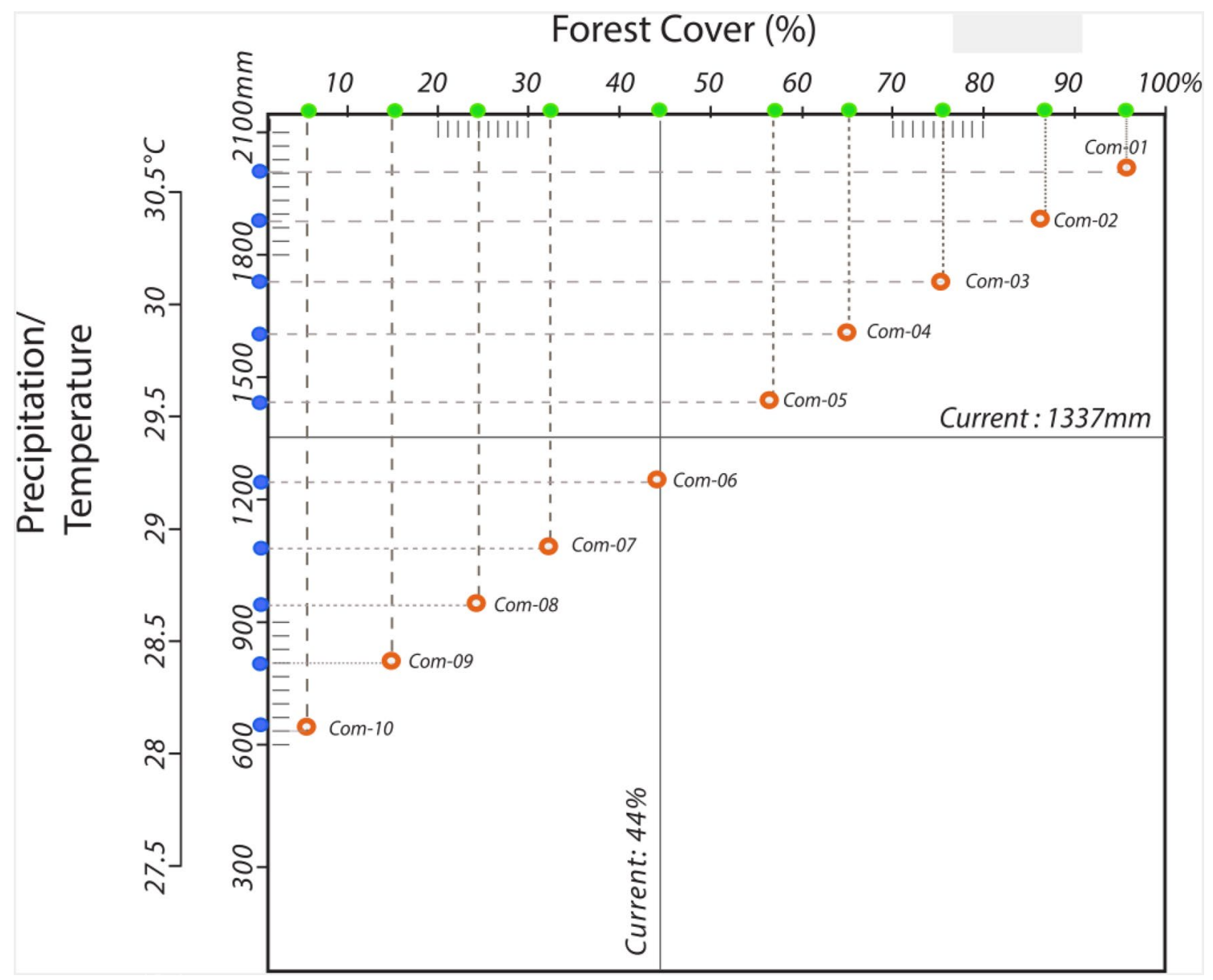

Fig. 5 Individual effect of LULC and climate change and combined effects

applied in this study because it does not require many parameters, and it is not limited geographically [43].

Among the six EMCs options, ecosystem conditions in this study were designated as ' $\mathrm{C}$ : Moderately modified', and our goal was to protect the basic function of the ecosystem in the Siem Reap River. During a field visit conducted by the first author, moderate river modifications were observed. There has been disturbance between the Angkor Temple complex and the Phnom Kulen range as well as downstream from Siem Reap City to Tonlé Sap (habitat modification). There were also diversion weirs and barays in the catchment. In addition, the basic ecosystem is sustained mainly by populations of native species that are still viable within the temple complex and the upper headwaters surrounding Phnom Kulen. Therefore, option C best reflects the current status of the catchment. Monthly streamflow observations from 1999 to 2018 were used to generate the environmental flows for the Siem Reap River.

More sophisticated methods, such as the habitat and holistic methods, have been used to calculate the environmental flows because they can provide finer resolution habitat surveys and thus a high degree of confidence. However, those methods require extensive field surveys, experts input and tend to be time consuming [43]. Therefore, in light of data and resource limitations, this study employed the Tennant method, which was the simplest and most common method [40], paired with GEFC software. The recommended environmental flows under both methods (Tenant and GEFC) for Siem Reap River were approximately $24 \%$ and $29 \%$ of the mean annual streamflow.

\subsection{SWAT model}

SWAT has been used to examine the influences of land management practices on the hydrology, sedimentation and water quality in agricultural basins [44]. It can be applied at both the sub-basin and the basin scales in order to examine the hydrological responses under the effects of land cover and climate changes [26]. It has been widely applied to investigate hydrologic response to various effects of land use change [45]. The SWAT 


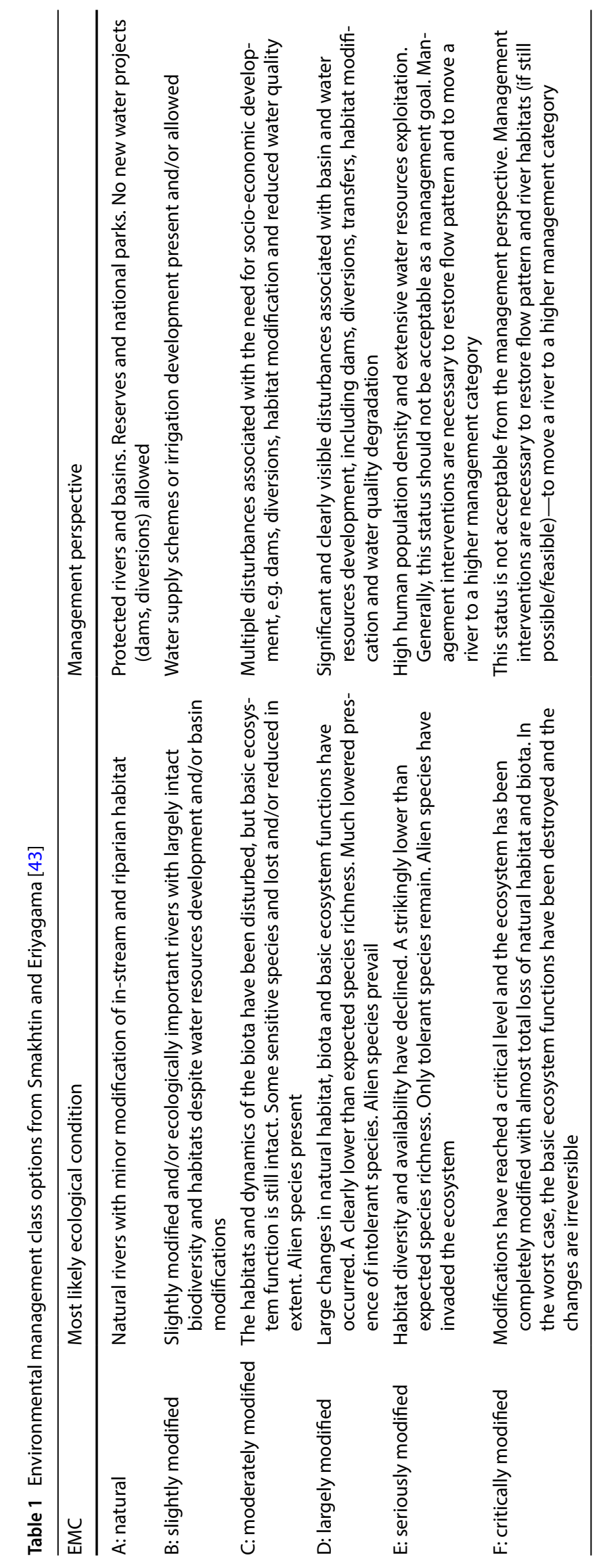


model software package has a user-friendly interface and it has been integrated into ArcGIS and QGIS software, and the resulting software packages are known as ArcSWAT [46] and QSWAT, respectively. SWAT was adopted in this paper to simulate both the individual and joint effects of land cover and climate variation in the upper Siem Reap catchment. The SWAT model is conceptualized using the following equation:

$\mathrm{SW}_{t}=\mathrm{SW}_{0}+\sum_{i=1}^{t}\left(R_{\text {day }}-Q_{\text {surf }}-E_{\mathrm{a}}-W_{\text {seep }}-Q_{\mathrm{gw}}\right)$

where $\mathrm{SW}_{t}$ : final soil water content $(\mathrm{mm}), \mathrm{SW}_{0}$ : initial soil water content $(\mathrm{mm}), R_{\text {day }}$ : amount of precipitation on day $i(\mathrm{~mm}), Q_{\text {surf }}$ : amount of surface runoff on day $i(\mathrm{~mm})$, $E_{\mathrm{a}}$ : amount of evapotranspiration on day $i(\mathrm{~mm}), W_{\text {seep }}$ : amount of percolation that bypasses the soil profile bottom on day $i(\mathrm{~mm}), Q_{\mathrm{gw}}$ : amount of groundwater return flow on day $i(\mathrm{~mm})$ [47].

Based on the review of Tarigan et al. [23] work on land use parameters and through the process of manual calibration and validation in this study watershed, the input parameters for each land use type were established (Table 2). However, actual parameters from field measurements of land use types should be done for future study in order to achieve more reliable model results.

Chim et al. (in review) investigated land use and climate change effects on the hydrology of the upper Siem Reap catchment; some of the optimized parameters from their calibration and validation of parameter values are used in this study, as presented in Table 3. The Nash-Sutcliffe efficiency (NSE) metric, the coefficient of determination $\left(R^{2}\right)$ and percentage bias (PBIAS) are employed to evaluate the model performance. The NSE value indicates how well the modelled outcome compares to the observation. (The value ranges from $-\infty$ to 1 and values close to 1 indicate a better fit between the simulated data and observation.) The $R^{2}$ represents the coherence of a regression between the modelled data and observation. (The value ranges from 0 to 1 , the higher value, the tighter the relationship between the simulated and observed data.) The PBIAS term shows the average tendency of the modelled data to be larger or smaller than the observation. (A value close to 0 indicates a better match between the modelled data and observation; positive and negative values represent overestimation bias and underestimation bias, respectively.)

The daily SWAT streamflow model produced a satisfactory performance, with an overall average NSE of 0.62 , an
Table 2 Input parameters of land use
Table 3 SWAT calibration parameter values for Siem Reap River (Chim et al. in review)

\begin{tabular}{lllll}
\hline $\mathrm{N}$ & Model parameters & Description & Agriculture & Forest \\
\hline 1 & CANMX & Canopy storage & 6.00 & 8.00 \\
2 & BLAI & Potential leaf area index & 3.00 & 6.00 \\
3 & ALPHA_BF & Baseflow recession constant & 0.12 & 0.24 \\
4 & EPCO & Plant uptake compensation factor & 0.90 & 0.95 \\
5 & RCHR_DP & Deep aquifer percolation fraction & 0.10 & 0.20 \\
6 & HYDGRP & Hydrologic soil group & $\mathrm{D}$ & $\mathrm{C}$ \\
7 & SOL_BD & Soil bulk density & 1.20 & 1.00 \\
8 & SOL_AWC & Available water capacity & 0.10 & 0.20 \\
9 & SOL_K & Saturated hydraulic conductivity & 600.00 & 1000.00 \\
10 & CN2 & Curve number & 58.00 & 48.00 \\
11 & OV_N & Manning's $n$ value for overland flow & 0.10 & 0.14 \\
\hline
\end{tabular}

\begin{tabular}{|c|c|c|c|c|c|}
\hline $\mathrm{N}$ & Parameters & Description & Min & Max & Calibrated value \\
\hline 1 & GW_DELAY & Groundwater delay & 0.00 & 500.00 & 1.00 \\
\hline 2 & GWQMN & Depth of water in the shallow aquifer for return flow & 0.00 & 5000.00 & 600.00 \\
\hline 3 & REVAPMN & Threshold depth of water in the shallow aquifer & 0.00 & 1000.00 & 600.00 \\
\hline 4 & LAT_TIME & Lateral flow travel time & 0.00 & 180.00 & 36.00 \\
\hline 5 & SLSOIL & Slope length for lateral subsurface flow & 0.00 & 150.00 & 80.00 \\
\hline 6 & $\mathrm{CH} \_\mathrm{N} 2$ & Manning's ' $n$ ' value for the main channel & 0.01 & 0.30 & 0.01 \\
\hline 7 & $\mathrm{CH} \_\mathrm{K} 2$ & Effective hydraulic conductivity in main channel & 0.01 & 500.00 & 36.00 \\
\hline 8 & $\mathrm{CH} \_\mathrm{N} 1$ & Manning's ' $n$ ' value for the tributary channels & 0.01 & 30.00 & 0.01 \\
\hline 9 & CH_K1 & Effective hydraulic conductivity in tributary channel & 0.00 & 300.00 & 120.00 \\
\hline
\end{tabular}


$R^{2}$ of 0.69 and PBIAS of -7.25 . The satisfactory model performance is reflected in values of NSE greater than 0.50 [48]. During the period of calibration, the NSE value is 0.69 , the $R^{2}$ value is 0.70 and the PBIAS is 0.30 . In the validation period the NSE value is 0.56 , the $R^{2}$ value is 0.68 and the PBIAS value is -14.80 .

SWAT Calibration and Uncertainty Program (SWAT-CUP) with Sequential Uncertainty Fitting (SUFI-2) algorithm was employed for sensitivity analysis of land use and climate parameters. The SUFI-2 analysis accounted for the principal uncertainties, including driving variables, model parameters and measured data [49]. A $p$-value has been used to determine the relative significance of individual parameter, and the parameters with higher value of $p$-values are least sensitive to the model outcome [50].

\section{Results}

\subsection{Sustainable water for Angkor Temple Complex}

Table 4 presents the current and future requirements for a sustainable water supply for the Angkor Temple Complex. The water demands $\left(W D_{\text {Current }}\right.$ and $\left.W D_{\text {Future }}\right)$ in the Angkor Temple Complex are approximately 68 and 111 million $\mathrm{m}^{3}$, respectively [30]. The evaporation losses $\left(E_{\text {Current }}\right.$ and $\left.E_{\text {Future }}\right)$ in the Angkor Temple Complex are approximately 32 and 48 million $\mathrm{m}^{3}$, based on the report from JICA [32]. The annual average environmental flow (Avg. EF) under the Tenant method and GEFC were around 59 and 71 million $\mathrm{m}^{3}$, respectively. An average value of 65 million $\mathrm{m}^{3}$ is used as the average annual environmental flow requirement for Siem Reap River.

Using Eqs. 1 and 2, the annual sustainable threshold (ST $\mathrm{Surrent}_{\text {and }} \mathrm{ST}_{\text {Future }}$ ) for the Angkor Temple Complex were determined to be $162 \pm 16$ million $\mathrm{m}^{3}$ and $224 \pm 22$ million $\mathrm{m}^{3}$, respectively. The plus and minus $10 \%$ were applied for the thresholds in this study to account the possible error and uncertainty. These could arise due to various factors, such as climate fluctuation, water demand estimation and evaporation losses. The annual distribution

Table 4 Annual sustainable threshold for the Angkor Temple Complex (million m3)

\begin{tabular}{llll}
\hline $\mathrm{N}$ & Description & \multicolumn{2}{l}{ The Angkor Temple Complex } \\
\cline { 3 - 4 } & Current $\left(\mathrm{M} \mathrm{m}^{3}\right)$ & Future $\left(\mathrm{M} \mathrm{m}^{3}\right)$ \\
\hline 1 & Water demand (WD) & 65 & 111 \\
2 & Evaporation loss (E) & 32 & 48 \\
3 & Average environmental flow & 65 & 65 \\
$\quad$ (Avg. EF) & & 224 \\
4 & Sustainable threshold (ST) & 162 & 20 \\
\hline
\end{tabular}

of precipitation and temperature varies from year to year and thus could influence the allocation of environmental flows. The timing of water storage may also lead to an underestimation of losses due to evaporation. The annual evaporation from JICA was measured as a whole for the Siem Reap River area, and this value might be a bit different at individual barays and moats in the complex due to different surrounding vegetation covers and local conditions. The bulk volume of water demand was provided by the Apsara Authority; since we do not know the matrix of their calculation (timing and allocations), this could lead to some additional error. Any outcome in our simulations where annual flows fall close to these levels (thresholds) indicates the sustainable threshold for water supply to the Angkor Temple Complex.

\subsection{Effect of LULC and climate changes on streamflow}

Figure 6 shows the average annual water yield, groundwater (GW) contribution to stream and evapotranspiration (ET) under the impact of LULC (solely) in the upper of Siem Reap watershed: the climate component (precipitation and temperature, 1999-2018) is unchanged. It can be seen that both water yield and GW responses have the same pattern, while the ET response has the opposite trend. The average annual water yield increases as the forest cover decreases and this outcome was in the line with the findings of Bruijnzeel [10], as well as for some catchments in south-east Asia [8] and in different catchments across the globe [9]. While the average annual water yield under $5 \%$ of forest cover (decreased $-39 \%$ relative to current land use) was 283 million $\mathrm{m}^{3}$, the annual average water yield under $95 \%$ forest cover (increase $+51 \%$ relative to current land use) was 251 million $\mathrm{m}^{3}$. As the forest cover shrank from 32 to $5 \%$ of the watershed (decrease -12 to $-39 \%$ relative to current land use), the annual average water yield increased from 274 to 283 million $\mathrm{m}^{3}$, which was about $+1.60 \%$ to $+5.00 \%$ relative to current conditions. Conversely, the annual average water yield decreased considerably, from 265 to 251 million $\mathrm{m}^{3}$ (about $-1.70 \%$ to $-7.10 \%$ ), as forest cover increased from 57 to $95 \%$ of the watershed (increase +13 to $+51 \%$ relative to the constant land use). While the average annual streamflow decreased from approximately $-2.56 \%$ as the forest cover increased from 44 to $65 \%$ of the watershed area (increase $+21 \%$ relative to the constant land use scenario), the average annual streamflow increased by approximately $+1.58 \%$ as the forest cover decreased from 44 to $32 \%$ of the watershed area (increase $+12 \%$ relative to the constant land use scenario). These results are not far from the findings of Wang et al. [20] in China, and Khoi and Suetsugi [16], in Vietnam using the SWAT model. Wang et al. [20] discovered that mean

SN Applied Sciences 
Fig. 6 Annual average water yield, groundwater contribution to stream (GW) and evapotranspiration (19992018) responses under LULC scenarios

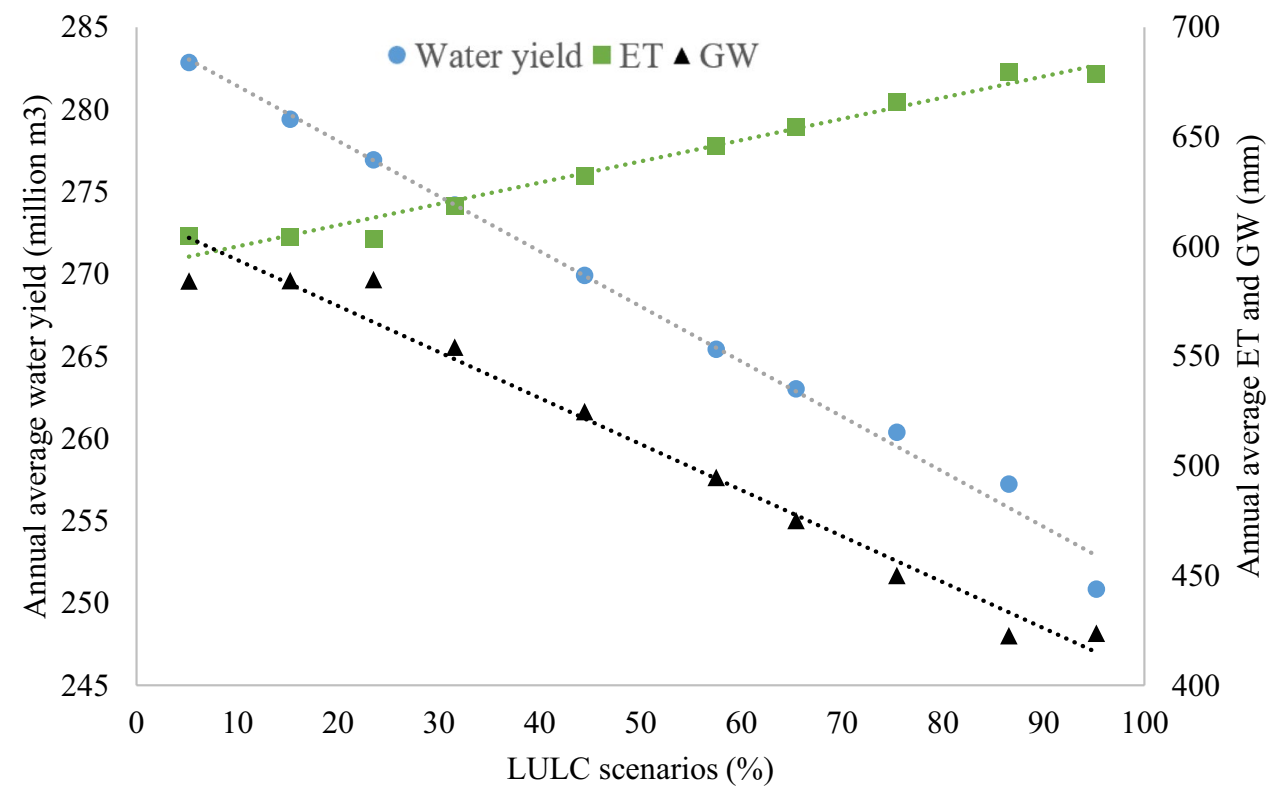

annual runoff dropped by $-2.3 \%$ followed by a rise $+25 \%$ of forest cover in a mountainous watershed in China. Similarly, Khoi and Suetsugi [16] discovered a rise of streamflow, from $+0.2 \%$ to $+0.4 \%$ with a decrease of $-16.3 \%$ in forest land.

Similar to streamflow response, the average annual GW contribution to the stream increases with decreasing forest cover. The average annual GW contribution under $5 \%$ of forest cover (decreased - 39\% relative to current land use) was $584 \mathrm{~mm}$ while the average annual GW contribution under $95 \%$ of forest cover (an increase of $+51 \%$ relative to current land use) was $424 \mathrm{~mm}$. However, the ET response under the impact of LULC change had a contrasting trend compared to the water yield and GW response. While the average annual ET under $5 \%$ of forest cover (decreased $-39 \%$ relative to current land use) was $605 \mathrm{~mm}$, the annual average ET under 95\% forest cover (increase $+51 \%$ relative to current land use) was $679 \mathrm{~mm}$. It can be seen that the average annual evapotranspiration decreased (around -13 to $-27 \mathrm{~mm}$ ) as the forest cover decreases from 32 to $5 \%$ (a drop of $-12 \%$ and - 39\% relative to the current conditions). Conversely, the average annual evapotranspiration rate increased by about $13 \mathrm{~mm}$ to $46 \mathrm{~mm}$ as the forest cover increases from 57 to $95 \%$ (an increase of +13 to $+51 \%$ relative to the constant land use scenario). The evapotranspiration increased linearly with the expansion of forest cover in the watershed.

Figure 7 shows the average streamflow and GW contribution to the stream during the dry season (in percentage) and the average annual amount of water storage in the soil (in percentage) under the LULC scenarios, relative to the current land use. Based on the model results, the average dry season of both streamflow and GW contribution responses relative to the constant land use is presented in Fig. 7a. It can be seen that the average streamflow in the dry season decreased from approximately -3.67 to $-7.82 \%$ as the forest cover decreased from 32 to $5 \%$ of the watershed area (decline of -12 to $-39 \%$ relative to the constant land use scenario). The average dry season streamflow, conversely, increased by around +1.69 to $+14.20 \%$ as the forest cover increased from 57 to $95 \%$ of the watershed (increase +13 to $+51 \%$ relative to the constant land use).

The average dry season GW contribution to streamflow also had a similar pattern to the average dry season streamflow. It can be noted that the average dry season GW contribution decreased around -27.8 to $-56.3 \%$ as forest cover decreased from 32 to $5 \%$ of the watershed (decrease -12 to $-39 \%$ relative to the constant land use). Conversely, the average dry season GW contribution increased by about $28.5 \%$ to $+98.6 \%$ as the forest cover increased from 57 to $95 \%$ of the watershed (an increase of $+13 \%$ to $+51 \%$ relative to the constant land use scenario). This finding was similar to the study of Ilstedt et al. [37] in West Africa. Ilstedt et al. [37] investigated groundwater recharge using Simile software, and they found that forest cover could lead to increased groundwater recharge by holding/storing the rainfall in the soil and releasing groundwater reserves more slowly during the dry season. Although there is an evident increase in groundwater contribution during the dry season, it is actually relatively small in comparison to groundwater contributions during rainy season. (For example, a 56\% change in the dry season is about equal to a $5 \%$ change in the rainy season.) However, under conditions of water stress, it could be a vital contribution at this time [8]. 
Fig. 7 a Average streamflow and GW contribution responses during dry season (\%) and $\mathbf{b}$ annual average amount of water stored in soil (\%) under different land use scenarios relative to constant land use scenario
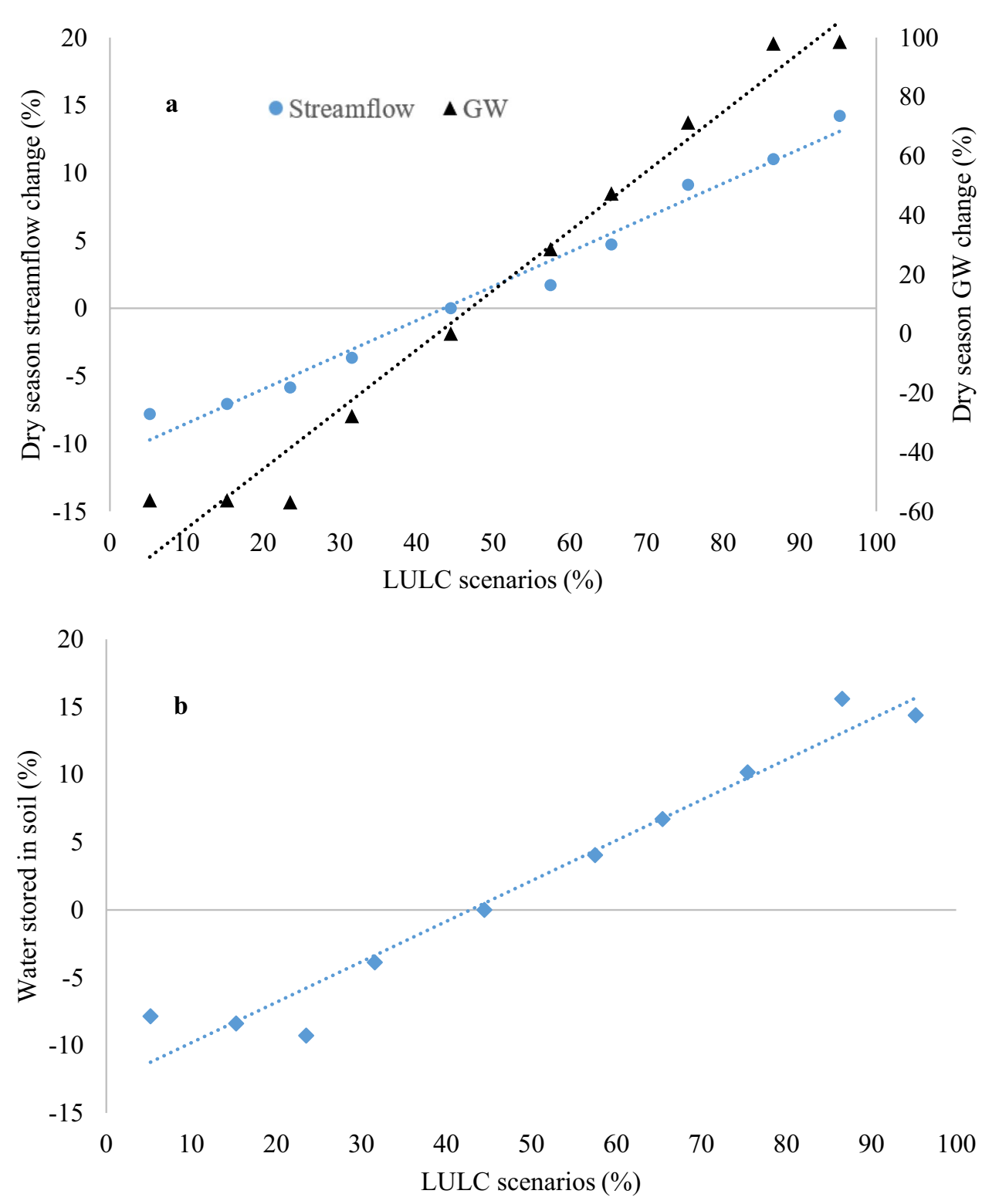

Figure $7 \mathrm{~b}$ presents the average annual proportion of water stored in soil under different LULC scenarios, relative to current land use. It may be observed that the average annual soil water storage decreased (around -3.88 to $-7.86 \%$ ) as the forest cover decreased by 32 to $5 \%$ of the watershed, representing -12 to $-39 \%$ relative to current conditions. The average annual proportion of water stored in soil, by contrast, increased from about 4.04 to $14.38 \%$ as the forest cover increased from 57 to $95 \%$ of the watershed ( +13 to $+51 \%$ relative to current conditions). The amount of water stored in the soil increases with the expansion of forest cover and thus the forest cover plays a crucial role in improving the available water storage capacity of the soil [9].

These model results show that forest cover could increase interception, which is an important contribution to the precipitation regime [36], and it could help retain soil moisture [9] in the watershed, which significantly improves the dry season streamflow $[9,10]$ as well as groundwater contribution [37]. On other hand, conversion of forest land into agricultural land can lead to a declining precipitation regime in the catchment $[51,52]$ thus decreasing streamflow and groundwater table.

Although every LULC scenario could generate a sufficient water supply for current and future conditions (water yield $>162$ and 224 million $\mathrm{m}^{3}$ ) within the Angkor Temple Complex, it is extremely important to consider the precipitation cycle, dry season flows and flood risk. Based on the results from the modelling work, it is clearly essential to maintain current forest cover (LULC 2018,44\%), because this has so far maintained the runoff regime, generated sufficient seasonal streamflow, and has reduced peak flood 
flows that could impact the Angkor Temple Complex and the surrounding townsite. However, further study of water demand and groundwater usage during the dry season in the Angkor Temple Complex should be carried out in order refine estimates of forest cover required. In addition, maintaining and increasing forest coverage through native-forest plantation in the watershed, particularly in the Phnom Kulen range, may be an effective and viable option. Forest cover can reduce surface temperature, better contribute to storage and yield to streams [36], thus increasing vital streamflow and groundwater stores during the dry season.

\subsection{Effect of climate changes on streamflow}

Table 5 summarizes the annual average water yield under the influence of climate change (solely) in the study watershed, as LULC is kept constant. The LULC 2018 scenario consists of $44 \%$ of forest and $56 \%$ of agriculture/ non-forest cover. It can be seen that as the annual average water yield decreases, precipitation declines and vice versa. The annual average water yield was approximately 63 million $\mathrm{m}^{3}$ when the precipitation decreased $-50 \%$ (the 'Clim-50\%' scenario) relative to the current precipitation. The annual average water yield, conversely, was 494 million $\mathrm{m}^{3}$ as the precipitation was increased to $+50 \%$ (the 'Clim + 50\%' scenario). Decreasing precipitation by more than $-20 \%$ and $-10 \%$ relative to the current precipitation regime could put water under stress for the current and future water supply in the Angkor Temple Complex, respectively. The annual average water yield was about 178 million $\mathrm{m}^{3}$ as the precipitation dropped $20 \%$ from the current climate condition and this annual average water yield was sufficient for the current storage ( $\mathrm{ST}_{\text {Current }}$ ) in the Angkor Temple Complex. In the case of a 10\% decrease in precipitation relative to the current climate condition, the annual average water yield was around 224 million $\mathrm{m}^{3}$ which was enough to accommodate the future storage $\left(\mathrm{ST}_{\text {Future }}\right)$ in the Angkor Temple Complex.

A shift in climate conditions of $\pm 50 \%$ from the current climate condition invariably has a significant impact on the modelled streamflow in the study watershed. Overall, climate change has a much greater impact on modelled streamflow results than LULC change.

\subsection{The combined effect of LULC and climate changes on streamflow}

Table 6 presents the annual average water yield under the combined influences of land cover and climate changes. The annual average water yield was about 474 million $\mathrm{m}^{3}$ under the combined effects of increasing precipitation and forest cover ( $+50 \%$ and $+51 \%$; 'Com -01 ' scenario) relative the current conditions. The annual average water yield was around 69 million $\mathrm{m}^{3}$ under the combined effects of decreasing precipitation and forest cover $(-50 \%$ and-39\%; 'Com-10' scenario) relative to current condition. The combination of decreasing precipitation and forest cover ( $-20 \%$ and $-12 \%$; the 'Com -07 ' scenario) relative to the current climate and land use condition could generate sufficient streamflow, at approximately 182 million $\mathrm{m}^{3}$ as an annual average, to meet current demands (ST Current $)$ in the Angkor Temple Complex. Furthermore, the combination of decreasing precipitation, by $10 \%$ relative to the current mean climate condition, and stable land use conditions (the 'Com - 06' scenario) could generate sufficient water yield ( 224 million $\mathrm{m}^{3}$ ), to supply the future storage $\left(\mathrm{ST}_{\text {Current }}\right)$ in the Angkor Temple Complex.

Forest cover was relatively insensitive as a governing variable, and this is consistent with our current understanding of land cover effects. The modelled streamflow
Table 5 Annual average water yield (1999-2018) responses under climate change scenarios relative to the sustainable thresholds for the Complex (in million $\mathrm{m}^{3}$ )

\begin{tabular}{lllllll}
\hline $\mathrm{N}$ & \multicolumn{2}{l}{ Climate change (\%) } & Scenario name & Water yield & $\mathrm{ST}_{\text {Current }}$ & $\mathrm{ST}_{\text {Future }}$ \\
\cline { 2 - 5 } & Precipitation & Temperature & & & \\
\hline 1 & +50 & $+10 \%$ & Clim $+50 \%$ & 494.03 & $>162$ & $>224$ \\
2 & +40 & $+9 \%$ & Clim $+40 \%$ & 447.10 & $>162$ & $>224$ \\
3 & +30 & $+8 \%$ & Clim $+30 \%$ & 401.05 & $>162$ & $>224$ \\
4 & +20 & $+7 \%$ & Clim $+20 \%$ & 355.13 & $>162$ & $>224$ \\
5 & +10 & $+6 \%$ & Clim $+10 \%$ & 310.28 & $>162$ & $>224$ \\
6 & -10 & $+5 \%$ & Clim $-10 \%$ & 224.19 & $>162$ & $>\mathbf{2 2 4}$ \\
7 & -20 & $+4 \%$ & Clim $-20 \%$ & 178.17 & $>162$ & $<224$ \\
8 & -30 & $+3 \%$ & Clim $-30 \%$ & 136.34 & $<162$ & $<224$ \\
9 & -40 & $+2 \%$ & $C l i m-40 \%$ & 97.28 & $<162$ & $<224$ \\
10 & -50 & $+1 \%$ & $C l i m-50 \%$ & 62.60 & $<162$ & $<224$ \\
\hline
\end{tabular}

The bold values are the sustainable thresholds for the current and future conditions of the Angkor Temple Complex 
Table 6 Annual average water yield (1999-2018) responses under combined scenarios relative to the sustainable thresholds for the Complex (in million $\mathrm{m}^{3}$ )

\begin{tabular}{|c|c|c|c|c|c|c|c|}
\hline \multicolumn{2}{|c|}{ LULC change (\%) } & \multicolumn{2}{|c|}{ Climate change (\%) } & \multirow[t]{2}{*}{ Scenario name } & \multirow[t]{2}{*}{ Water yield } & \multirow[t]{2}{*}{$\mathrm{ST}_{\text {Current }}$} & \multirow[t]{2}{*}{$\mathrm{ST}_{\text {Future }}$} \\
\hline Forest & Agriculture & Precipitation & Temperature & & & & \\
\hline 95 & 5 & +50 & $+10 \%$ & Com-01 & 473.89 & $>162$ & $>224$ \\
\hline 87 & 13 & +40 & $+9 \%$ & Com-02 & 433.80 & $>162$ & $>224$ \\
\hline 75 & 25 & +30 & $+8 \%$ & Com-02 & 391.14 & $>162$ & $>224$ \\
\hline 65 & 35 & +20 & $+7 \%$ & Com-02 & 348.13 & $>162$ & $>224$ \\
\hline 57 & 43 & +10 & $+6 \%$ & Com - 05 & 305.89 & $>162$ & $>224$ \\
\hline 44 & 56 & -10 & $+5 \%$ & Com-06 & 224.19 & $>162$ & $>224$ \\
\hline 32 & 68 & -20 & $+4 \%$ & Com - 07 & 181.77 & $>162$ & $<224$ \\
\hline 24 & 76 & -30 & $+3 \%$ & Com -08 & 141.45 & $<162$ & $<224$ \\
\hline 15 & 85 & -40 & $+2 \%$ & Com-09 & 100.81 & $<162$ & $<224$ \\
\hline 5 & 95 & -50 & $+1 \%$ & Com -10 & 69.38 & $<162$ & $<224$ \\
\hline
\end{tabular}

The bold values are the sustainable thresholds for the current and future conditions of the Angkor Temple Complex results were most sensitive to the effects of climate change. The combined effect has a similar, though slightly moderated response magnitude, reflecting the minimal role of land cover on mean annual streamflow water yield. The sensitivity parameters for model variables representing land use and climate are summarized in Table 7. A high $p$-value parameter indicates a lesser influence on streamflow generation within the model. It can be seen that the ALPHA_BF, PCPMM, SOLARAV and LAT_TTIME were the most sensitive parameters, with statistically significant $p$-values $(p<0.05)$. For climate parameters, SOLARAV and TMPMX were ranked as the most sensitive parameters in terms of their influence on streamflow results. The land use parameters related to
Table 7 Model parameters sensitivity

\begin{tabular}{llll}
\hline N & Parameters & Description & $p$-value \\
\hline 1 & CANMX & Canopy storage & 0.60 \\
2 & BLAI & Potential leaf area index & 0.69 \\
3 & ALPHA_BF & Baseflow recession constant & $\mathbf{0 . 0 0}$ \\
4 & EPCO & Plant uptake compensation factor & 0.45 \\
5 & RCHR_DP & Deep aquifer percolation fraction & 0.94 \\
6 & SOL_BD & Soil bulk density & 0.64 \\
7 & SOL_AWC & Available water capacity & 0.58 \\
8 & SOL_K & Saturated hydraulic conductivity & 0.36 \\
9 & CN2 & Curve number & 0.18 \\
10 & OV_N & Manning's $n$ value for overland flow & 0.98 \\
11 & PCPMM & Average amount of precipitation falling in month & $\mathbf{0 . 0 0}$ \\
12 & SOLARAV & Average daily solar radiation in month & $\mathbf{0 . 0 0}$ \\
13 & TMPMX & Average maximum air temperature for month & 0.23 \\
14 & TMPMN & Average minimum air temperature for month & 0.73 \\
15 & GW_DELAY & Groundwater delay & 0.28 \\
16 & GWQMN & Depth of water in the shallow aquifer for return flow & 0.62 \\
17 & REVAPMN & Threshold depth of water in the shallow aquifer & 0.79 \\
18 & GW_REVAP & Groundwater'revap' coefficient & 0.98 \\
19 & LAT_TTIME & Lateral flow travel time & $\mathbf{0 . 0 4}$ \\
20 & SLSOIL & Slope length for lateral subsurface flow & 0.67 \\
21 & CH_N1 & Manning's ' $n$ ' value for the tributary channels & 0.93 \\
22 & CH_K1 & Effective hydraulic conductivity in tributary channel & 0.55 \\
23 & CH_N2 & Manning's ' $n$ ' value for the main channel & 0.21 \\
24 & CH_K2 & Effective hydraulic conductivity in main channel & 0.54 \\
\hline & & &
\end{tabular}

The bold values are the most sensitive parameters 
forest and agriculture cover, for instance CANMX, BLAI and EPCO, did not have a strong impact $(p>0.05)$ on the model results. We can see from these results that climate parameters, particularly precipitation, have a much stronger effect on streamflow generation than land use parameters, e.g. forest cover. However, soil parameters such as ALPHA_BF, CN2 and SOL_K had a significant and important influence on streamflow generation in the study watershed.

\section{Discussion}

The results from the SWAT model show that streamflow is relatively insensitive to land use change, but quite highly sensitive to climate change, similar to the findings of Khoi and Suetsugi [16] in Vietnam. It has been well documented by many researchers that decreasing forest cover will lead to increased water yield $[9,10]$. Similarly, this study also found that increase annual streamflow resulted from the reduction of forest cover. However, this study carried out further investigation into the impact of forest cover on the dry season streamflow and groundwater contribution to stream and the amount of water storage in soil and found that there were increasing streamflow, groundwater contribution and soil moisture responses during dry season under expansion of forest cover. The outcome of increasing streamflow was also reported in some catchments in south-east Asia [10], in the Panama [53] and various catchments around the world [9]. Even though the contribution of forest cover to streamflow change in the dry season might be small, but it could alleviate pressures on water supply in the watershed [8]. Likewise, llstedt et al. [37] also found that forest cover could increase groundwater recharge during the dry season. Moreover, forest cover could improve soil moisture [9] and groundwater recharge which potentially enhance the groundwater table and streamflow during the dry season.

Although every scenario of LULC can produce sufficient water to supply the Angkor Temple Complex, the results from this study help to emphasize that current forest cover (44\%) should be maintained, since the current runoff regime and groundwater can generate sufficient water supply for the Angkor Temple Complex, especially in the dry season. The streamflow and groundwater levels during dry season are extremely important, particularly in light of competing requirements to maintain hydrostatic conditions within the temple foundations, and the high-water demand due to the large number of local tourists, who normally visit the temple in April, the Khmer New Year. Temperatures in the dry season are high, and there is almost no rainfall in the watershed, exacerbating the problem. Thus, further study on water demand and groundwater usage in the dry season in the Angkor Temple Complex and the Siem Reap City should be carried out. It is crucial to develop a finer-grained picture of water demand in the Complex and city during the dry season so that we can come up with possible and practical plans and solutions to protect the Angkor Temple Complex.

Overall, despite the finding that water yield is increased by reduction of forest cover, forest land plays crucial role in hydrologic processes, such as maintained precipitation cycle, protected flooding and improved dry season streamflow and groundwater storage. Forest cover plays a vital role in balancing the evapotranspiration regimes and maintaining the rainfall cycle [36]. According to Van der Ent et al. [54], evapotranspiration contributes at least $40 \%$ of precipitation on Earth, and the Amazon forest contributes more than $70 \%$ of precipitation for the Rio de Plata river basin. Transpiration contributes a large share of evapotranspiration in the atmosphere [55]. Furthermore, the forest cover can increase interception and evapotranspiration and then it can lead to reduced flood-related catastrophes [11]. It should be noted that this study does not cover the linkages between forest cover and precipitation, it does point to the importance of better establishing sustainable forest cover targets in order to enhance hydrological function in monsoon-dominated systems.

This study applied a homogenous category of forest and agriculture covers which might not present the natural conditions of the catchment. Different types of actual parameters (CANMX, BLAI, EPCO, CN and ALPHA_BF) of forest cover types and cropping systems should be considered since their functions influence water yield in different ways. It is important to note that more detailed forest and agriculture cover types would be useful for future iterations of the model. Moreover, the hydrological gauge stations should be installed in the river upstream, inside the weir and canal system (particularly on the main canals and inlet of barays) of the Angkor Temple Complex as well as on Pouk and Rolous Rivers. These not only contribute to improved accuracy of future studies, but it also helps the water managers to better allocate water resources and direct development in the Angkor Temple Complex.

\section{Conclusion}

The SWAT model was applied to examine the individual and joint effects of land cover and climate variability on river flow in the upper Siem Reap catchment. This river is well known for the religious and cultural heritage as well as national identity to the people and the country. Water 
management in the Siem Reap River is different from ordinary rivers because of the amount of water required to maintain the Angkor Temple Complex. The required water supply to sustain current and future conditions in the Angkor Temple Complex was assessed to be $162 \pm 16$ million $\mathrm{m}^{3}$ and $226 \pm 22$ million $\mathrm{m}^{3}$ annually (respectively, including evaporation loss and environmental flows).

Every scenario of land use change could produce sufficient streamflow to supply both current and future storages in the complex, if the climatic conditions are kept constant (i.e. 1999-2018 temperature and precipitation regime). In the modelled climate change scenarios, decreasing precipitation by $-20 \%$ (the 'Clim - 20\%' scenario) and $-10 \%$ (the 'Clim - 10\%' scenario) from the current precipitation could generate sufficient water supply for the current and future water supply in the Angkor Temple Complex, respectively. Moreover, the combined scenario of decreasing precipitation and forest cover ( $-20 \%$ and $-12 \%$; the 'Com -07 ' scenario) relative to the current climate and land use condition could produce enough streamflow to supply the current storage requirements in the Angkor Temple Complex. The combination of decreased precipitation relative to current conditions ( $-10 \%$; the 'Com-06' scenario) could also generate sufficient streamflow for the future storage requirements in the Angkor Temple Complex. Finally, the outcome of this paper will better inform water managers and decision makers and help them to weigh the effects of changing streamflow under individual and joint impacts of land use and climate changes. Planning practical solutions to mitigate those effects will be a significant priority, going forward.

Acknowledgement The authors wish to gratefully acknowledge the ASEAN New Zealand Scholarship, Ministry of Water Resource and Meteorology, Siem Reap Provincial Department of Water Resources and Meteorology, ASPARA Authority and local authority, Cambodia. The authors also would like to thank supervisors, anonymous reviewers and editors for their valuable comments and suggestions that helped to improve the manuscript.

Author contributions KC conducted data collection, model running, analysed the results and wrote the manuscript. JT and AS supervised the research, provided comments, reviewed and edited the manuscript. SS facilitated in data collection and provided consultation on results.

\section{Compliance with ethical standards}

Conflicts of interest Authors declare no conflict of interest.

Open Access This article is licensed under a Creative Commons Attribution 4.0 International License, which permits use, sharing, adaptation, distribution and reproduction in any medium or format, as long as you give appropriate credit to the original author(s) and the source, provide a link to the Creative Commons licence, and indicate if changes were made. The images or other third party material in this article are included in the article's Creative Commons licence, unless indicated otherwise in a credit line to the material. If material is not included in the article's Creative Commons licence and your intended use is not permitted by statutory regulation or exceeds the permitted use, you will need to obtain permission directly from the copyright holder. To view a copy of this licence, visit http://creativecommons .org/licenses/by/4.0/.

\section{References}

1. Oeurng C, Cochrane TA, Chung S, Kondolf MG, Piman T, Arias ME (2019) Assessing climate change impacts on river flows in the Tonle Sap Lake Basin. Cambodia 11:618. https://doi. org/10.3390/w11030618

2. UNESCO (2017) Angkor water crisis. https://en.unesco.org/couri er/2017-april-june/angkor-water-crisis. Accessed 24 July 2019.

3. Winter T (2008) Post-conflict heritage and tourism in Cambodia: the burden of Angkor. Int J Heritage Stud 14:524-539. https:// doi.org/10.1080/13527250802503274

4. Baillie B (2006) Conservation of the sacred at Angkor Wat: further reflections on living heritage. Conserv Manag Archaeol Sites 8:123-131. https://doi.org/10.1179/175355206×265788

5. Carter AK, Stark MT, Quintus S, Zhuang Y, Wang H, Heng P, Chhay R (2019) Temple occupation and the tempo of collapse at Angkor Wat. Cambodia 116:12226-12231. https:// doi.org/10.1073/pnas.1821879116

6. Jia Q, Wang X, Zhang Y, Cao L, Fox AD (2018) Drivers of waterbird communities and their declines on Yangtze River floodplain lakes. Biol Conserv 218:240-246. https://doi. org/10.1016/j.biocon.2017.12.029

7. Liu Z, Yao Z, Huang H, Wu S, Liu G (2014) Land use and climate changes and their impacts on runoff in the Yarlung Zangbo river basin, China. Land Degrad Dev 25:203-215. https://doi. org/10.1002/ldr.1159

8. Farley KA, Jobbagy EG, Jackson RB (2005) Effects of afforestation on water yield: a global synthesis with implications for policy. Glob Chang Biol 11:1565-1576. https://doi.org/10.11 11/j.1365-2486.2005.01011.x

9. Brown AE, Zhang L, McMahon TA, Western AW, Vertessy RA (2005) A review of paired catchment studies for determining changes in water yield resulting from alterations in vegetation. $J$ Hydrol 310:28-61. https://doi.org/10.1016/j.jhydrol.2004.12.010

10. Bruijnzeel LA (2004) Hydrological functions of tropical forests: not seeing the soil for the trees? Agric Ecosyst Environ 104:185228. https://doi.org/10.1016/j.agee.2004.01.015

11. Bradshaw CJ, Sodhi NS, Peh KS, Brook BW (2007) Global evidence that deforestation amplifies flood risk and severity in the developing world. Glob Chang Biol 13:2379-2395. https://doi. org/10.1111/j.1365-2486.2007.01446.x

12. Gaughan AE, Binford MW, Southworth J (2009) Tourism, forest conversion, and land transformations in the Angkor basin, Cambodia. Appl Geogr 29:212-223. https://doi.org/10.1016/j.apgeo g.2008.09.007

13. Le Billon P (2000) The political ecology of transition in Cambodia 1989-1999: war, peace and forest exploitation. Dev Chang 31:785-805

14. Chim K, Tunnicliffe J, Shamseldin A, Ota T (2019) Land use change detection and prediction in upper Siem Reap River. Cambodia 6:64. https://doi.org/10.3390/hydrology6030064

15. Costenbader J, Broadhead J, Yasmi Y, Durst PB (2015) Drivers affecting forest change in the greater mekong subregion (GMS): an overview. FAO, Rome 
16. Khoi DN, Suetsugi T (2014) The responses of hydrological processes and sediment yield to land-use and climate change in the Be River Catchment. Vietnam Hydrol Process 28:640-652. https ://doi.org/10.1002/hyp.9620

17. Hu Q, Willson GD, Chen X, Akyuz A (2005) Effects of climate and landcover change on stream discharge in the Ozark Highlands. USA 10:9-19. https://doi.org/10.1007/s10666-004-4266-0

18. Thoeun HC (2015) Observed and projected changes in temperature and rainfall in Cambodia. Weather Clim Extrem 7:61-71. https://doi.org/10.1016/j.wace.2015.02.001

19. Yan R, Huang J, Wang Y, Gao J, Qi L (2015) Modeling the combined impact of future climate and land use changes on streamflow of Xinjiang Basin. China 47:356-372. https://doi. org/10.2166/nh.2015.206

20. Wang S, Kang S, Zhang L, Li F (2008) Modelling hydrological response to different land use and climate change scenarios in the Zamu River basin of northwest China. Hydrol Process 22:2502-2510. https://doi.org/10.1002/hyp.6846

21. Sayasane R, Kawasaki A, Shrestha S, Takamatsu M (2015) Assessment of potential impacts of climate and land use changes on stream flow: a case study of the Nam Xong watershed in Lao PDR. J Water Clim Chang 7:184-197. https://doi.org/10.2166/ wcc. 2015.050

22. Tan ML, Ibrahim AL, Yusop Z, Duan Z, Ling L (2015) Impacts of land-use and climate variability on hydrological components in the Johor River basin. Malaysia 60:873-889. https://doi. org/10.1080/02626667.2014.967246

23. Tarigan S, Wiegand K, Slamet B (2018) Minimum forest cover required for sustainable water flow regulation of a watershed: a case study in Jambi Province. Indonesia 22:581-594. https:// doi.org/10.5194/hess-22-581-2018

24. Ghaffari G, Keesstra S, Ghodousi J, Ahmadi H (2010) SWAT-simulated hydrological impact of land-use change in the Zanjanrood basin, Northwest Iran. Hydrol Process 24:892-903. https://doi. org/10.1002/hyp.7530

25. Wu K, Johnston CA (2007) Hydrologic response to climatic variability in a Great Lakes Watershed: a case study with the SWAT model. J Hydrol 337:187-199. https://doi.org/10.1016/j.jhydr ol.2007.01.030

26. Abbaspour KC, Yang J, Maximov I, Siber R, Bogner K, Mieleitner J, Zobrist J, Srinivasan R (2007) Modelling hydrology and water quality in the pre-alpine/alpine Thur watershed using SWAT. J Hydrol 333:413-430. https://doi.org/10.1016/j.jhydr ol.2006.09.014

27. Benavides-Solorio J, Flores-Garnica JG, Moreno-Gonzalez DA (2007) Assessing runoff and suspended sediment using SWAT Under Different Land uses in Tapalpa. Jalisco, Mexico

28. Kummu M (2003) The natural environment and historical water management of Angkor, Cambodia

29. Siem Reap Provincial Department of Water Resources and Meteorology (2019) Climate data in Siem Reap Province

30. Apsara Authority Officials (2019) Personal communication

31. Fletcher R, Penny D, Evans D, Pottier C, Barbetti M, Kummu M, Lustig T (2008) The water management network of Angkor. Cambodia 82:658-670. https://doi.org/10.1017/S0003598X000972 95

32. JICA (2000) The study on water supply system for Siem Reap region in Cambodia. Final report, prepared by the Japan International Cooperation Agency (JICA) for the Ministry of Industry, mines, and energy - The Royal Government of Cambodia

33. Leith C (2019) Challenges facing the Siem Reap Tuk-Tuk Workforce in a changing Tourism Environment: 166

34. ADB (2014) CAM: Urban water supply project-Siem Reap Subproject. Prepared by Ministry of Industry and Handicraft for the Asian Development Bank
35. Stocker et al (2013) Climate change 2013: the physical science basis: working group I contribution to the fifth assessment report of the intergovernmental panel on climate change.

36. Ellison D, Morris CE, Locatelli B, Sheil D, Cohen J, Murdiyarso D, Gutierrez V, Van Noordwijk M, Creed IF, Pokorny J (2017) Trees, forests and water: cool insights for a hot world. Global Environ Chang 43:51-61. https://doi.org/10.1016/j.gloen vcha.2017.01.002

37. Ilstedt U, Tobella AB, Bazié HR, Bayala J, Verbeeten E, Nyberg G, Sanou J, Benegas L, Murdiyarso D, Laudon H (2016) Intermediate tree cover can maximize groundwater recharge in the seasonally dry tropics. Sci Rep 6:21930. https://doi.org/10.1038/srep2 1930

38. Allen A, Chapman D (2001) Impacts of afforestation on groundwater resources and quality. Hydrogeol J 9:390-400. https://doi. org/10.1007/s100400100148

39. Tharme RE (2003) A global perspective on environmental flow assessment: emerging trends in the development and application of environmental flow methodologies for rivers. River Res Appl 19:397-441

40. Nikghalb S, Shokoohi A, Singh VP, Yu R (2016) Ecological regime versus minimum environmental flow: comparison of results for a river in a semi Mediterranean region. Water Resour Manage 30:4969-4984. https://doi.org/10.1007/s11269-016-1488-2

41. Karimi SS, Yasi M, Eslamian S (2012) Use of hydrological methods for assessment of environmental flow in a river reach. Int $J$ Environ Sci Technol 9:549-558

42. Shokoohi A, Amini M (2014) Introducing a new method to determine rivers' ecological water requirement in comparison with hydrological and hydraulic methods. Int J Environ Sci Technol 11:747-756. https://doi.org/10.1007/s13762-013-0404-z

43. Smakhtin VU, Eriyagama N (2008) Developing a software package for global desktop assessment of environmental flows. Environ Model Softw 23:1396-1406. https://doi.org/10.1016/j.envso ft.2008.04.002

44. Gassman PW, Reyes MR, Green CH, Arnold JG (2007) The soil and water assessment tool: historical development, applications, and future research directions. Transac ASABE 50:1211-1250. https://doi.org/10.13031/2013.23637

45. Baker TJ, Miller SN (2013) Using the soil and water assessment tool (SWAT) to assess land use impact on water resources in an East African watershed. J Hydrol 486:100-111. https://doi. org/10.1016/j.jhydrol.2013.01.041

46. Olivera F, Valenzuela $M$, Srinivasan $R$, Choi J, Cho $H$, Koka $S$, Agrawal A (2006) ArcGIS-SWAT: a geodata model and GIS interface for SWAT. J Am Water Resourc Assoc 42:295-309. https:// doi.org/10.1111/j.1752-1688.2006.tb03839.x

47. Neitsch SL, Arnold JG, Kiniry JR, Williams JR (2011) Soil and water assessment tool theoretical documentation version 2009

48. Moriasi DN, Arnold JG, Van Liew MW, Bingner RL, Harmel RD, Veith TL (2007) Model evaluation guidelines for systematic quantification of accuracy in watershed simulations. Transac ASABE 50:885-900. https://doi.org/10.13031/2013.23153

49. Kumar N, Singh SK, Srivastava PK, Narsimlu B (2017) SWAT Model calibration and uncertainty analysis for streamflow prediction of the Tons River Basin, India, using sequential uncertainty fitting (SUFI-2) algorithm. Model Earth Syst Environ 3:30. https://doi. org/10.1007/s40808-017-0306-z

50. Abbaspour K, Vaghefi S, Srinivasan R (2017) A guideline for successful calibration and uncertainty analysis for soil and water assessment: a review of papers from the 2016 International SWAT Conference. doi: https://doi.org/10.3390/w10010006

51. Oliveira LJ, Costa MH, Soares-Filho BS, Coe MT (2013) Large-scale expansion of agriculture in Amazonia may be a no-win scenario. 
Environ Res Lett 8:024021. https://doi.org/10.1088/17489326/8/2/024021

52. Lawrence D, Vandecar K (2015) Effects of tropical deforestation on climate and agriculture. Nat Clim Chang 5:27. https://doi. org/10.1038/nclimate2430

53. Ogden FL, Crouch TD, Stallard RF, Hall JS (2013) Effect of land cover and use on dry season river runoff, runoff efficiency, and peak storm runoff in the seasonal tropics of Central Panama. Water Resour Res 49:8443-8462. https://doi.org/10.1002/2013W R013956
54. der Ent V, Rudi J, Savenije HH, Schaefli B, Steele-Dunne SC (2010) Origin and fate of atmospheric moisture over continents. Water Resour Res. https://doi.org/10.1029/2010WR009127

55. Schlesinger WH, Jasechko S (2014) Transpiration in the global water cycle. Agric For Meteorol 189:115-117. https://doi. org/10.1016/j.agrformet.2014.01.011

Publisher's Note Springer Nature remains neutral with regard to jurisdictional claims in published maps and institutional affiliations. 